\title{
SEM study of Sandersiella chilenica sp.nov. (Cephalocarida), with a review of the Integumentary Structures and Functional Adaptations in the Group
}

\author{
Estudio con microscopia de barrido de Sandersiella chilenica n. sp. (Cephalocarida), \\ con una revisión de las Estructuras del Integumento y Adaptaciones Funcionales en el \\ Grupo
}

\author{
José R. Stuardo \& René Vega \\ Universidad de Concepción, Casilla 160-C, Concepción, CHILE. \\ E-mail: jstuardo@udec.cl.
}

\begin{abstract}
RESUMEN
Se describe Sandersiella chilenica sp.nov., Cefalocárido encontrado en la pequeña Bahía de Coliumo, Chile central $\left(36^{\circ}\right.$ 32' lat S.; 7256' long W), en un solo punto de una grilla de 11 estaciones estudiadas mensualmente durante 198283, en fondos con predominancia de arena fina, limo y arcilla. Sólo otras cuatro especies del género son conocidas (Sandersiella acuminata Shiino, 1965 y S.kikuchii Shimomura \& Akiyama, 2008, de Japón, S. calmani Sanders \& Hessler, 1973 encontrada frente a la costa de Perú, y S.bathyalis Hessler \& Sanders, 1973 de Walvis Ridge, Atlántico S.E. y frente a Santos, Brasil). S. chilenica sp.nov. es diferenciable por una longitud máxima relativamente mayor, las ramas caudales más cortas y proporcionalmente más gruesas, y por la forma orbicular del segundo podomero del exopodito del toracópodo 6 . El estudio de la morfología externa con microscopia de barrido nos ha permitido proponer la diferenciación y clasificación de setas y otras estructuras cuticulares externas, siguiendo las clasificaciones propuestas para Crustáceos en general, reconociendo que falta clarificar si se trata de simples analogías o de verdaderas homologías.
\end{abstract}

Palabras clave: Crustacea, Cephalocarida, Chile central, microscopia de barrido, estructuras cuticulares.

\begin{abstract}
The Cephalocarid, Sandersiella chilenica sp. nov. from Coliumo Bay, Central Chile ( $36^{\circ} 32^{\prime}$ S lat.; $72^{\circ} 56^{\prime}$ W long) is described. The new species was collected at only one bottom station (station 4) in a grid of 11 stations sampled monthly during 1982-83, with predominating fractions of fine sand, silt and clay. Four other species of the genus are so far known (Sandersiella acuminata Shiino 1965, and S.kikuchii Shimomura \& Akiyama, 2008, from Japan, S. calmani Hessler \& Sanders 1973 from off Perú, and S. bathyalis Hessler \& Sanders 1973, from Walvis Ridge, and off Namibia, SE Atlantic, and off Santos, Brazil). S. chilenica sp. nov, is differentiated from each of these by its comparatively greater maximal length, its shorter and proportionally thicker caudal rami, and the orbicular form of the second podomere of the exopod in thoracopod 6. A SEM study of the external morphology has allowed us to propose the differentiation of setae and other external cuticular body structures following the classifications proposed for Crustacea in general, although possible analogies or homologies need yet to be clarified.
\end{abstract}

KeYwords: Crustacea, Cephalocarida, central Chile, SEM, cuticular body structures.

\section{INTRODUCTION}

Over two decades have passed since the discovery of a new species of Sandersiella in a small bay near Concepción, Central Chile. A first draft with its description including the external and some internal parts of the species was sent abroad for comments but unfortunately received very little feedback. Shortly thereafter the well known series of papers on the ultrastructure of parts of the internal and external systems of Hutchinsoniella macracantha Sanders, 1955, gave rise to a wealth of new detailed anatomical and functional information now available to the students of this remarkable group ( Elofsson \& Hessler 1990,1991,1992; Elofsson et al. 1992; Hessler \& Elofsson 1991, 1992, 1995; 
Hessler et al. 1995; Read et al. 1994 ). However, in contrast to the 9 species and 4 genera proposed between 1955 and 1977 , only one genus and three new species have been proposed during the last years as part of the specialized literature on this group: a) the description of the new genus Hampsonellus based on the redescription of a species from Brazil formerly adscribed to Sandersiella bathyalis Hessler \& Sanders, 1973 (Wakabara \& Mizoguchi 1976), now the type species H.brasiliensis Hessler \& Wakabara, 2000; b) the description of Lightiella magdalenina Carcupino et al., 2006, the only species of Cephalocarida known from European waters, followed by the study of its larval development by Addis et al. (2007), and c) the description of Sandersiella kikuchii Shimomura \& Akiyama, 2008 from off the central coast of Japan.

Several interesting studies on the microhabitat and general ecology of given Cephalocarida species by Heard \& Goeke (1982); De Troch et al. (2000); Schiemer \& Ott (2001); Martin et al. (2002) have added to the knowledge of the general ecology of the group and primitive benthic marine invertebrates, in general.

Thus, twelve species, belonging to five genera (three of them monotypic) have been described to date, with records ranging from tropical to cold temperate environments and from the intertidal to about 1559m depth (Abele 1982). (See a recent list with morphological and cladistic characters of the first eleven species by Carcupino et al. 2006). None has yet been registered from polar or subpolar conditions. South American records correspond to an undetermined species from off Río de la Plata (Bastida 1973), H. brasiliensis Hessler \& Wakabara, 2000 from Brazil and Sandersiella calmani Hessler \& Sanders, 1973 from off Perú and northern Chile (R.Soto, Universidad Arturo Prat, personal communication). Three other species of Sandersiella are presently known: S.acuminata Shiino, 1965 from Tomioka Bay, Mukaishima and off Shikoku, Japan ( Kikuchi 1969; Shimomura \& Akiyama 2008); S. bathyalis Hessler \& Sanders, 1973 from off Walvis Bay, Southwest Africa and off Brazil (Schram 1986), and S. kikuchii from off central Japan (Shimomura \& Akiyama 2008).

This paper describes Sandersiella chilenica sp.nov, froma coastal embayment in Central Chile, with an analysis of its external morphology relevant to the taxonomy and general anatomy of the group, in the light of the present available information. The species name refers to the geographic area where it was found, to call attention to the still sparse distribution of the group, no doubt, largely the result of the difficulty to identify these minute animals in large bottom samples.

Research was carried out under Project 203703 Dirección de Investigación, Universidad de Concepción, Chile.

\section{MATERIAL AND METHODS}

The studied specimens of the new species were obtained from July, 1982 to November, 1983, while carrying out a survey of the bottom fauna at Coliumo Bay, near Concepción, Chile ( $36^{\circ} 32^{\prime} \mathrm{S}$ lat.; $72^{\circ} 56^{\prime} \mathrm{W}$ long.).

Bottom samples were taken with a $0.1 \mathrm{~m}^{2}$ Smith-McIntyre grab in a total of 11 scattered stations, covering a range of sandy to predominantly silty clay bottoms. The species was found only on the western part of the small bay ( station 4 ), in depths of 4 to $6 \mathrm{~m}$ with predominant granulometric fractions of fine sand, silt and clay. All sorted invertebrates were preserved in the field in 5\% buffered formaldehyde and transferred after some days to $70 \%$ ethanol. Specimens were measured under a stereoscopic microscope and various supplementary observations such as molting condition and presence of eggs were also registered. Measurements and ratios for each specimen will be supplied on request.

Three specimens were clarified in lactic acid and dissected for light microscopy observations; 3 others were prepared for scanning electron microscopy following the techniques recommended by Jones \& Fordy (1971) for isopods, but dried in a $\mathrm{CO}_{2}$ critical point dryer; 3 additional specimens were embedded for histological sectioning and treated with Hematoxylin-eosin, PAS, Masson and van Gieson stains. SEM samples were examined with an Autoscan U-1 Siemen ETEC and photographed on Kodak Plus-x, 21 DIN film.

Results are presented under two headings : A) sensory setae and other integumentary structures; and B) the description of Sandersiella chilenica sp.nov. In turn de discussion covers the broader aspects of taxonomic and diagnostic features (C); functional remarks (D), and ecological remarks (E).

\section{RESULTS}

A. SENSORY SETAE AND OTHER INTEGUMENTARY STRUCTURES IN Crustacea and Cephalocarida. Cephalocarids, like other crustaceans, probably use the many hair-like projections of the cuticle, usually referred to as setae for external tactile and chemical stimulation. Unfortunately, in describing species authors often utilize different names for similar or apparently identical structures.

In other groups of crustaceans, several types of setae have been described (see Thomas 1970, Pohle \& Telford 1981, Hamilton 1983, Stuardo et al. 1986, and particularly the comprehensive reviews by Felgenhauer 1992, and Garm 2004, with full references ) and it is our impression that stronger emphasis should be given to the observed differences in armature to serve taxonomic purposes and 
functional interpretations. Details of armature associated with the body cuticle in Crustacea have been largely clarified by the combined utilization of scanning electron microscopy (SEM) for morphological differentiation and transmission electron microscopy (TEM) for ultrastructural studies. It was the high degree of morphological differentiation observed on the body and appendages that led to the proposals attempting to establish a classification of the different types recorded. However, as early pointed out by Laverack (1968) for Crustacea in general, it cannot be assumed that all serve the same function.

McLaughlin (1976) in describing Lightiella floridana called attention to this problem, and proposed to use Roman numerals to represent spines in setation formulae. Nonetheless, loose denominations remained and names such as "long strap-like filamentous structure", "long annulated filament', "sensory flagellum" and "flagellum" designating the long aesthetasc of antenna 1, or "large stiff spines", "annulated setae", "stout setae", "small setae", "curved setae", "long stiff setae", "indented spines", teeth, claws, coarse setules, etc., to designate the complex setal types found on the last segments of antenna 1, and other appendages have been used by different authors. Moreover, the first antenna and its aestethasc were not mentioned in the original descriptions of Sandersiella calmani and S.bathyalis by Hessler and Sanders (1973). In fact, there seems to be no general agreement as to a definition of what a Crustacean "seta " is per se, and the classifications largely follow the first important proposal by Thomas (1970), with adjustments.

According to Felgenhauer (1992:22) the term "seta" in higher Crustacea is used to describe "a wide range of morphological structures from robust spines and scales to fine setal shafths armed with delicate setules". However, he follows the system proposed by Watling (1989) for integumentary structures recognizing the following general setal types: 1) Simple; 2) Hamate (squat setae); 3) Plumose; 4) Pappose; 5) Serrate; 6) Serrulate; 7) Multidenticulate, and 8) Plumodenticulate. He further recognizes the following additional structures: 9) Spines; 10) Denticles; 11) Scales; and a generalized "Surface sculpturing", considering: 12) CAP or cuticular articulated peg organs; 13) Funnel canal organs; 14) Hair-fan organs; 15) the Tuft organ, and 16) various tegumental scale sensilla. Felgenhauer (1992) defines spine (9) as " a non-articulated cuticular extension of the exoskeleton that has a base that is generally not as wide as the structure is long; regardless of its size or shape, a spine has no socket"; denticles (10) "are more robust rounded spines", and scales (11) "are not nearly as common as spines and tubercles and may be separate articulating structures in themselves or a microarmature of longer setae in the form of setules as in multidenticulate setae" Regarding the surface sculpture he comments: "The surface of the cuticule may be decorated by grooves or depressions that correspond to insertions by muscle groups; or may vary from rugous tubercles arming the entire animal ... to highly organized ridges...found arming the dorsal carapace ... associated with a very thick calcified exoskeleton", adding that it is very difficult to assign a function to the overall rugous sculpturing. Paradoxically, he does not define "setule", one of the most used names in the literature.

The last revision of this problem by Garm (2004) based on the external morphology and ultrastructure of the setae found in the mouthparts of seven species of Decapoda led him to propose a reconsideration of the basic types differentiating setae (two types), setules and denticles as basic major types and grouping the setae in the following seven types: pappose, plumose, serrulate, serrate, papposerrate, simple and cuspidate. He optimizes this classification identifying the different names proposed by Thomas (1970) and ensuing authors since the 70s onwards with each of his seven types. Out of this comparison, he concludes that: "A seta is an elongate projection with a more or less circular base and a continuous lumen; the lumen has a semicircular arrangement of sheath cells basally". Yet, his concept of "denticle" is very different to that of Felgenhauer (1992), defining it as "very small (1-30 $\mu \mathrm{m}$ long), smooth, flat and pointed projections with no articulated socket..." and, "...no outgrowth, no pore and no lumen". In turn, considers "setule" as: "Medium sized $(2-150 \mu \mathrm{m})$, flat and elongate projections with an articulation in a socket area...normally serrated along the distal edge... they always lack a pore"...". They are made solely of cuticle and with no associated cells...", and ... "found on many of the setae". He adds another very important observation: "Even though denticles and setules are often very distinct and easy to separate, there are intermediate forms. In some cases rows of outgrowths gradually changing from setules to denticles (from base to tip) can be found on the same seta (his figure $4 \mathrm{G})$ ". He also points out that "setules may have a lumen distally, but it never continues through the entire projection".

Although these two general classifications (Felgenhauer 1992 and Garm 2004) attempt to make the terminology applicable to sensory structures associated with the body cuticle in Crustacea more precise, the study of Cephalocarid species disclose differences. These are blind and minute animals of the infaunal benthos, whose setation and sensorial tegumentary structures become particularly important to understand general behavior, interactions with the environment and niche differentiation. Yet, setae and related morphological structures, seem to follow a similar although simpler plan of geometric growth and distribution of setules and denticles, resembling the types found in higher Crustacea, but with important differences. Unfortunately, given their small size and the low number of genera and species known so far, a general description of the body parts using light microscopy, plus an assumed apparent uniformity of morphology and function, have discouraged a detailed study of setal differentiation. 


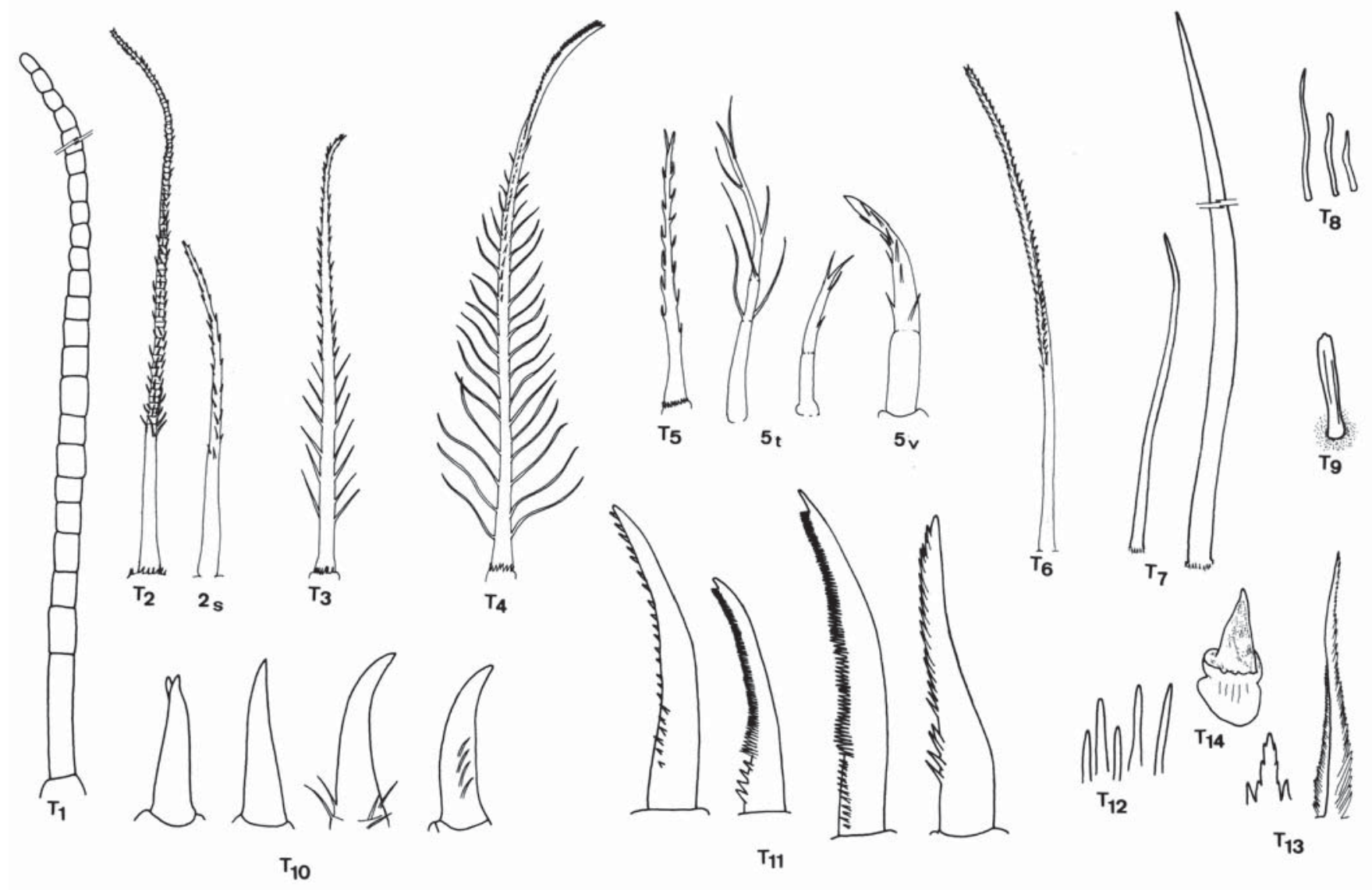

Figure 1. Types of setae (T) in Sandersiella chilenica sp.nov. (Size not proportional; measurements in $\mu \mathrm{m}$ and $\mathrm{mm}$ ).

1, aesthetasc ( 0.4- $0.8 \mathrm{~mm}) ; 2$, pappose-like seta $(0.04-0.5 \mathrm{~mm}) ; 2 \mathrm{~s}$, pappose- like setae, small type; 3, plumose setae (21-209 $\mu \mathrm{m})$; 4 , plumose-serrate setae $(0.1-0.4 \mathrm{~mm})$; 5 , bifid setae $(30-100 \mu \mathrm{m})$; $5 \mathrm{t}$ bifid or trifid setae on gnathobase $(20-57 \mu \mathrm{m})$; $5 \mathrm{v}$, variation of the same type on thoracopod seven; 6 , serrate-like seta $(0.05-0.2 \mathrm{~mm})$; 7 , caudal setae $(0.1-1.5 \mathrm{~mm}) ; 8$, simple setae ( $3-37 \mu \mathrm{m})$; 9 , setae in pits $(2-10$ $\mu \mathrm{m}) ; 10$, conate or spine-like setae (11-57 $\mu \mathrm{m}) ; 11$, indented or claw-like setae (22-159 $\mu \mathrm{m}) ; 12$, simple spine $(2-8 \mu \mathrm{m})$; 13 , serrate spine ( 30-106 $\mu \mathrm{m})$; 14, squat-spoon shaped spine ( ca. $50 \mu \mathrm{m})$.

Figura 1. Tipos de setas (T) observados en Sandersiella chilenica sp.nov. (Tamaño no proporcional; medidas en $\mu \mathrm{m}$ y mm).

1, estetasco $(0,4-0,8 \mathrm{~mm}) ; 2$, paposa $(0,04-0,5 \mathrm{~mm})$ : 2s, paposa tipo pequeño; 3, plumosa $(21-209 \mu \mathrm{m})$; 4, plumosa-aserrada $(0,1-0,4$ $\mathrm{mm}) ; 5$, bífida $(30-100 \mu \mathrm{m}) ; 5 \mathrm{~g}$ bífida o trífida en gnathobase $(20-57 \mu \mathrm{m}) ; 5 \mathrm{v}$ variación del mismo tipo en toracópodo siete; 6 , aserrada (0,05- 0,2 mm) ; 7, caudal (0,1- 1,5 mm); 8, simple (3- $37 \mu \mathrm{m})$; 9, seta en hoyos (2- $10 \mu \mathrm{m})$; 10, como-cono o espina (11-57 $\mu \mathrm{m})$; 11 , indentada o ganchuda $(22-159 \mu \mathrm{m}) ; 12$, espina simple $(2-8 \mu \mathrm{m}) ; 13$, "diente" o espina aserrada (30-106 $\mu \mathrm{m})$; 14, espina gruesa acucharada

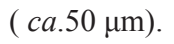

In fact, beyond the initial detailed description of the body parts and appendages given by Sanders (1955) for $H$. macracantha, and in spite of his magnificent observations on this species behavior, it has been concluded that the most important specific and generic differentiations seem largely based on the type of reproduction and the optimization of body parts involved on this process. Moreover, the limitations of light microscopy to show important details, have indeed restrained the study of a nomenclature based on the real differentiation of setal characteristics adapted to function in a microcosmos not yet fully understood, originating an a priori consensus of apparent uniformity in morphology and function, and preventing further work on the detail of sensorial structures. Our general study of setal differentiation in Sandersiella chilenica sp. nov. shows that there is not such uniformity and that a preliminary approach to establish different types can fortunately be done by a comparison with the setal characteristics found in higher Crustacea. 
We follow Thomas (1970) in identifying setae as long chitinized projections of the cuticle arising from well-developed sockets, and spines as heavily cuticularized projections without sockets. The term setule is restricted to secondary projections found on setae and hair-like structures covering other parts of the body; to precise if they are made solely of cuticle deserves further ultrastructural work. The concept of scale differs from former interpretations, here referring to small platelike cuticular structures covering the appendages as in other Crustaceans. Furthermore, detailed SEM observations on the new species some corroborated in SEM photographs of Lighthiella magdalenina by Carcupino et al. (2006), allow us to differentiate and propose the following setal types (Figs.1 $\mathrm{T}_{1-14}, 2-4$; Pls. 1-3) and other cuticular outgrowths hoping to stimulate its study in the group.

A). Setae proper

1. Aesthetasc (aesthete) (Figs.1 $\mathrm{T}_{1}, 2 \mathrm{a}$; P1.1 F,I) (0.4$0.8 \mathrm{~mm}$ ).Extremely long, cylindric, annulated (segmented) sensory seta with wide lumen, arising from a short stalk without secondary outgrowths and forming bead-like articles towards the end. Present only on the last segment of antenna 1.

2. Pappose-like setae (Fig. $1 \mathrm{~T}_{2,2 \mathrm{~s}}$; Pl. 1 D, F, G) (0.04$0.5 \mathrm{~mm})$. Showing a wide range of sizes, and clear external annulations. With a smooth basal part, followed by short setules (some with pores ?) growing off the shaft at all angles but tapering down to 2 rows on the last third. Present on all segments of antenna 1 and exopod of antenna 2. A smaller type (Fig. 1, 2s) is found on maxilla 2 and the thoracopods.

3. Plumose setae (Fig. $1 \mathrm{~T}_{3}$; Pl. 2 G) $(21-209 \mu \mathrm{m})$. Long feather-like setae with two sets of long setules growing out of the shaft in two opposite rows. Found on the endites of maxilla1, the endopod of maxilla 2 and thoracopods 1 to 7 .

4. Plumose-serrate setae (Fig. $1 \mathrm{~T}_{4}$; Pl. 1 F, H, J right) $(0.1$ $0.4 \mathrm{~mm}$ ) Very long, feather-like setae with two rows of opposing setules and one alternate row of stiff shorter setules along one side, which replaces the other two rows towards the tip. Found on the exopod of maxilla 1 , the exopod and pseudepipod of maxilla 2, and all thoracopods.

5. Bifid or trifid setae (Figs. 1, $\mathrm{T}_{5,5 \mathrm{t}, 5 \mathrm{v}}$; Pls. 1F, 2 H, 3 A) (20$100 \mu \mathrm{m})$. Medium sized setae with sharp bifid or trifid end, and often a faint basal constriction. Two main types were disclosed, with variations: a) a longer bifid one with two opposing rows of short setules; and b) a shorter trifid type with 1 or 2 longer isolated terminal setules. Found on the exopod of maxilla 2 and thoracopod 5 and the gnathobase of maxilla 2 and thoracopods.1-7. A variation is also found on the endopod of thoracopod 7 ( Fig. 4, b).

6. Serrate-like setae (Fig. $1 \mathrm{~T}_{6}$; Pl.3 B) (0.05-0.2mm). Very long setae with serrations-like setules inserted in two opposing rows, set about $45^{\circ}$ to one another. Found on the 5 th segment of the endopod of maxilla 2 and thoracopods 1-7.

7. Caudal setae (Fig. $1 \mathrm{~T}_{7}$; Pl. 3 F,I) (0.1-1.5mm). Long or extremely long, acuminate-like, smooth setae. Found on the tip of the caudal rami. Also called terminal spines or terminal setae.

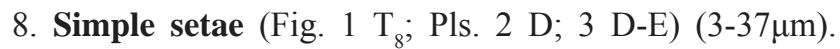
Short or comparatively longer, isolated or densely packed smooth setae with terminal pore. Found packed on the "lateral line" and loosely isolated on the appendages and the abdomen. They become longer on the labrum, around the anus and on some appendages.

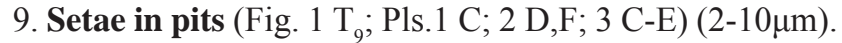
Short stout isolated simple setae, growing out of large pits. They show a granulated surface and one edge covered with longitudinal cords. Found on the "lateral line", the caudal rami and loosely distributed on the dorsal parts of the body and ventrally on the abdomen.

\section{B) SPINE-Like or ClaW-LiKe SETAE}

A number of stout, short setae have been named and listed as spines or claws by different authors. The following types are here differentiated:

10. Conate or spine-like setae (Fig. $1 \mathrm{~T}_{10}$; Pls. 1,D; 2 B, H) $(11-17 \mu \mathrm{m})$. Short, stoutly built, sharply conical or bifid setae, often with lateral slit. They can be either smooth, with opposing pairs of minute basal setules, or with a lateral row of such setules. Found on the gnathobases (endites) of maxilla 2, of thoracopods 1-7 and the endopod of antenna 2.

11. Indented or claw-like setae (Fig. $1 \mathrm{~T}_{11}$; Pls. $1 \mathrm{D}, \mathrm{E} ; 3$ B) $(22-159 \mu \mathrm{m})$. Stoutly built setae of various sizes with a row of partly lateral, separated, bladed denticles near the annular base. These in turn, give way to either a row of closely packed, long bladed denticles, or serrations. Found on the last segment of the endopod of antenna 2 , last segments of the endopods of maxilla 2 and thoracopods 1-7.

C) SPINES

As formerly defined, spines have no socket. We recognize two types on $S$. chilenica sp.nov.:

12. Small smooth spines (Fig. 4, T $_{12}$; Pls. 1 D,I; 3 B,H) (2$8 \mu \mathrm{m})$. Usually growing around the base of large setae, or arranged in rows bordering scales. These are the "stiff setules" of other authors. Also found on the distal parts and surface of all segments, on every appendage and on the ventral posterior margin of the abdomen and the telson.

13. Serrate spines or "Teeth" (Fig. $1 \mathrm{~T}_{13}$; Pl. 3 F,G,H) (30$106 \mu \mathrm{m})$. Long, thick spines with spatulate and strongly serrate lateral extensions. Found on the pretelsonic 
comb. A short modification of this type forms the telsonic comb.

14. Squat-spoon shaped spines (Figs. 1, $4 \mathrm{~T}_{14} ; \mathrm{Pl} .2 \mathrm{H}$ ) (ca. $50 \mu \mathrm{m}$ ), single or fused, growing out of a massive crownlike base. It is not clear if this spine is accompanied by one or two sensilla emerging from the base as observed on a similar type found on the carpus and merus of all pereiopods in the isopod Ionella agassizi Bonnier, 1900 (Stuardo et al. 1986b, fig. 23). Found on the endites of thoracopods 6 and 7 .

D) SCALes

An armature of thin overlapping true scales growing out of the body cuticle are found on the external part of the distal podomeres of maxilla 2 and the thoracopods - no doubt protecting them from abrasion -, being clearly delimited by lines of fringing small setae or spines depending on the degree of sclerotization (Pls. 1 F; 2 E) (Also observed, although not described in Lightiella magdalenina Carcupino et al., 2006; their figures 1B and 3C). Similar plates of larger size are found on various appendages of higher Crustacea (e.g. Isopoda; see Laverack \& Barrientos 1985, fig. 9 of a pereiopod in Eurydice pulchra and Stuardo et al. 1986a, plate 2, fig. 5, showing scales on the antennules of Pseudione brattstroemi ), apparently serving the same function.

These are not the "scales" described by Elofsson \& Hessler (1991) as discussed below.

E) "Lateral line" and "sensorial patches"

SEM images of the body surface indicate a complex arrangement of sensorial areas, two of which are presently described, namely the "lateral line" and "sensorial patches". The pleural borders of the abdominal segments (also named lateral spines) present a band of tiny, densely packed simple setae (Pl. 2, A (arrows); 3, C (arrows) D, E ) with pores. This band is well developed on all segments and reaches in rudimentary form even part of the caudal rami. No structure of this type has been mentioned before. Due to its small size, gross histological sectioning did not yield clear internal details. Single, larger, Type 9 isolated setae growing out of pits were also present within this band. Every other of these larger setae was found to be close to a pit or pore-like structure with a central bilobed valve-like opening (Pl. 2, D; 3 , C-E, and insertion ). On the average, two of such openings were observed per segment. These isolated pits might be equivalent to the larger "pores" described by Elofsson \& Hessler (1994), as discussed below. One or two setae of type 9 were found in such concavities. No interpretation can be advanced on the functional role of these two kinds of structures.

\section{B. Sandersiella chilenica sp.nov.}

MATERIAL EXAMined

Seventeen specimens in 4 lots collected during 1982 and
1983 make up the studied series; however, only 8 were selected as the type series, as detailed below:

Lot 1: 11 specimens (1 with eggs; 2 with hatched eggs). Station 4a and 4b; 6m depth, mud. July 13, 1982. Of this total, one specimen was mounted for histological sections, another one for SEM observations and 3 dissected for light microscopy observations. The remaining 6 specimens selected as Paratypes are kept at the Museum of Zoology, University of Concepción (MZUdeC $\mathrm{N}^{\text {os }}$ 35266 to 35271). Specimen № 35266 will be deposited at the Smithsonian Institution, Washington.

Lot 2: 2 specimens. Station 4; $6 \mathrm{~m}$ depth, mud. December 9, 1982. Holotype, with developing embryos (MZUC No 35264), and Paratype (MZUdeC № 35265 ).

Lot 3: 2 specimens. Station 4; $6 \mathrm{~m}$ depth, mud. One from July 13, 1982, and 1 from September 1, 1982, were used for histological sectioning, as well. The set of mounted slides is kept under MZUdeC No 35271.

Lot 4: 2 specimens. Station 4; 4m depth, mud. October 26, 1983. Mounted for SEM observations.

For comparative purposes the description of the new species generally follows the standards used to describe the other species of the genus, although the differentiation and proposal of the already discussed new setal types (Figure 1) made it necessary to introduce their names in the description. In the case of the appendages the words podomere and segment are used indistinctly.

\section{DESCRIPTION}

General body. Cephalon wider than long, about $20-30 \%$ of the total body length ( $24 \%$ in holotype), caudal rami excluded. Antero lateral margins with a ventral row of hooks-looking folds, all but the first two or three anteriorly directed (Fig. 2 e; Pl. 2 C); cephalon plus thorax equal $43-51 \%$ of the total length ( $46.5 \%$ in holotype). Thoracic pleurae well developed, slightly narrowing backward; pleurae of the seventh thoracic segment with more acute posterior corner turned backwards. Pleurae of abdominal segments moderately developed. Abdominal segments comparatively narrow; penultimate one well developed, with an evenly arched ventral comb of long, sharp teeth with serrate margins (Pl. 3, F,H). Telsonic segment narrower and shorter than preceding segment, about 1.8-2.2 times wider than long, with a posterior dorsal rise delimited by 2 lateral spines (Pl. $2 \mathrm{~A}$, star)). Ventrally, with a narrow, evenly comb about $0.36-0.5$ times the width of telson (Pl. 3 F,G). Caudal rami thick, comparatively short, markedly conical (Pl. $3 \mathrm{~F}$ ), its length (medial) 1.0-1.3 times the width of telson (1.2 in holotype). With 4 caudal smooth setae on each ramus, only one thicker than the other two and nearly as long as the abdomen, placed on the distal medial tip of the caudal $\operatorname{rami}(\mathrm{Pl} .3 \mathrm{I})$. 
Holotype body length (caudal rami excluded): $3.5 \mathrm{~mm}$; maximum width of thorax $0.63 \mathrm{~mm}$; maximum width of abdomen $0.38 \mathrm{~mm}$. Largest paratype length: $4.32 \mathrm{~mm}$; maximum width of thorax $0.85 \mathrm{~mm}$; maximum width of abdomen: $0.38 \mathrm{~mm}$.

Antenna 1 (Fig. 2 a; Pl.1 A,F,I). Of six segments or podomeres; second podomere almost twice as long as broad, bearing two pappose-like setae $\left(\mathrm{T}_{2}\right)$ toward the distal end; podomere 3 approximately half as long as podomere 2 , with a row of stiff setules on the external margin and a tuft of 6-7 pappose-like setae $\left(\mathrm{T}_{2}\right)$ of different sizes on the distal margin; podomeres 4 and 5 short, wider than long; 5 longer than 4 and each, half as long as number 3; podomere 6 the narrowest, twice as long as wide, tapering distally and bearing 9 different sized distal pappose-like setae $\left(\mathrm{T}_{2}\right)$ and a long aesthetasc $\left(\mathrm{T}_{1}\right.$ Pl. 1 F,I) of near regular joints. Total setal count is $0,2,6-7,0,0,9$ papposelike setae + aesthetasc.

Antenna 2 (Fig. 2 b, c; Pls.1 A,D,F,G; ). Resembling those of other species. Protopod of two short, stout podomeres: proximal one ill-defined, apparently unarmed; second one with 2 pappose setae $\left(T_{2}\right)$ at its ventral distal margin and, another one on the inner distal border of the swollen endopod base. Endopod characteristic, with two long, somewhat palmate podomeres. First podomere with one long and one thin, short plumose setae $\left(\mathrm{T}_{3}\right)$ on a ventral projection; second one 1.2 times longer than segment 1 , bearing an indented $\left(\mathrm{T}_{11}\right)$ and a shorter spine-like setae $\left(\mathrm{T}_{10}\right)$ and 3 long pappose-like adjoining setae. External surface of podomere 1 with irregular rows of fringing small smooth spines ( $\mathrm{T}_{12}$, stiff setules of authors); external surface of podomere 2 densely covered with small simple setae $\left(\mathrm{T}_{8}\right)$ and a distal row of small fringing spines $\left(\mathrm{T}_{11}\right)$. The thick and stout exopod articulates directly with the second protopod segment and consists of 19 short annuli of subequal length, gradually decreasing in width towards the apex. Each annulus has a series of 1 to 4 pappose-like $\left(T_{2}\right)$ distal setae, ventro-laterally placed and is externally covered with a dense mat of small setae of similar size; ventrally all appear smooth, except for irregular fringing rows of the above named small smooth spines (Plate 1 D,F,I). Table 1 presents a comparative total setal count of the exopod of antenna 2 in Sandersiella species.

Mandible (Fig. 2 d). Palpless; molar process (of the medial surface) with 5 stout bicuspidate teeth and several fine, smaller ones in-between; incisor process bicuspidate with a tiny medial bifid seta; one comparatively smaller thin seta observed behind the molar process.

Maxilla 1 (Fig. 3 a). Protopod with elongated gnathobase bearing distally 2 indented $\left(\mathrm{T}_{11}\right)$ and 2 plumose setae $\left(\mathrm{T}_{3}\right)$, and a disto-lateral one near the insertion of the exopod. Endopod of 4 longer than wide podomeres approximately of the same size; the first one slightly expanded proximally, its articulation with the protopod imprecise; podomeres 2 and 3 with a plumose $\left(\mathrm{T}_{3}\right)$ disto-medial, inner seta; distal end of podomere 4 divided into a short lateral lobe with 2 long plumose setae $\left(\mathrm{T}_{3}\right)$ and a flat slightly oblique median portion with 2 shorter ones. The exopod is a single flattened plate, almost three times as long as wide and extending to the proximal part of segment 2 of the endopod; 13 plumose-serrate setae $\left(\mathrm{T}_{4}\right)$ are distributed along its entire external margin but the inner medial border is smooth. See Table 2, for a comparative setal count of maxilla 1, in Sandersiella species.

Maxilla 2 (Fig. 3 b. Pls. 1 A, E, F; 2 E).Protopod developed medially into five lobes (endites) bearing from proximal to distal 5, 4, 3, 4 and 3 (bifid and conate, $\mathrm{T}_{5}, \mathrm{~T}_{10}$ ) setae. Endopod of six distinct segments: podomeres 1 to 4 similar, each medio-distal slightly wider than long having 1, 2, 4 and 2 differently sized plumose setae $\left(\mathrm{T}_{3}\right)$; podomere 5 longer than wide, about two times longer than podomere 4 , with one short medio-distal plumose seta and a latero-distal cluster of 6 serrate-like setae $\left(\mathrm{T}_{6}\right)$ (becoming progressively longer inwards); podomere 6 small, less than one third as long as number 5 , slightly wider than long, bearing 1 short conate $\left(\mathrm{T}_{10}\right)$ and 2 stout claw-like setae $\left(\mathrm{T}_{11}\right)$ also growing progressively longer laterally; each one with the first denticles sharp, larger and medially directed. Exopod of two segments: podomere 1 more than twice as long as wide, extending to the proximal edge of podomere 4 of the endopod; with 4 medial plumose setae $\left(\mathrm{T}_{3}\right)$ and one lateral; articulation with the protopod imprecise; podomere 2 flattened, oblong, longer than 1, more than twice as long as wide and extending beyond segment 6 of the endopod; with 13 closely set, plumose-serrate setae $\left(\mathrm{T}_{4}\right)$ along the medial and distal margins and the distal half of the lateral margin, and 5 smaller bifid setae $\left(\mathrm{T}_{5}\right)$ intercalated among the longer ones, also observed in the thoracopods. Pseudepipod somewhat similar in shape to the second exopod podomere but broader, about twice as long as wide and extending to the proximal part of the exopod of podomere 2; with 7 plumose-serrate setae $\left(\mathrm{T}_{4}\right)$ sparsely arranged around the distal margin. For comparative setal count of maxilla 2 in Sandersiella species, see Table 2. 


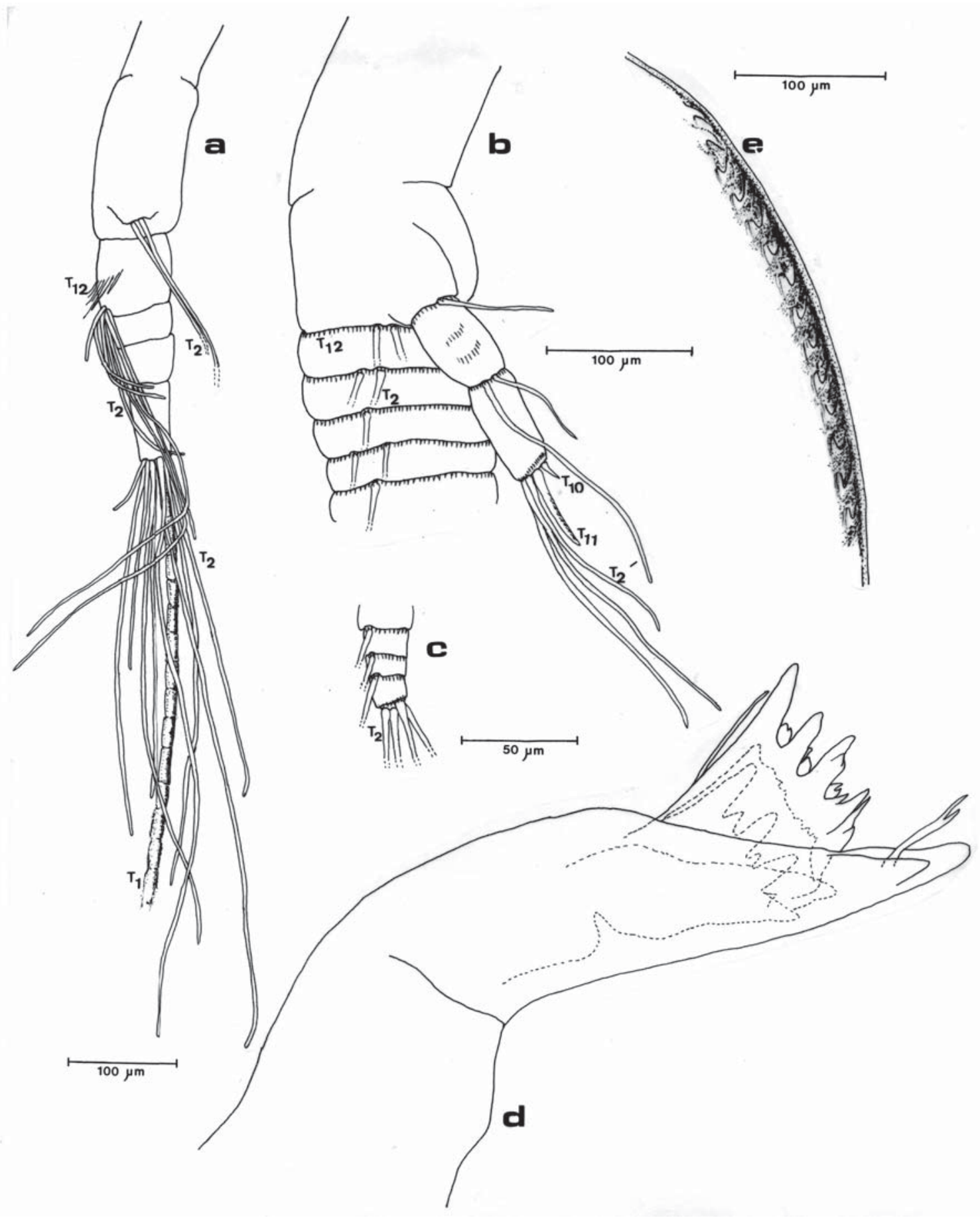

Figure 2. Appendages and setae in Sandersiella chilenica sp.nov. (dissected specimen). a) Right antenna 1. b) Antenna 2, exopod end excluded. c) Antenna 2, distal part of the exopod. d) Left mandible. e) Row of "cephalic hooks" observed with light microscopy and SEM.

Figura 2. Apéndices y setas en Sandersiella chilenica sp. nov. (ejemplar disectado). a) Antena derecha 1. b) Antena 2, extremo del exopodo excluido. c) Antena 2, parte distal del exopodo. d) Mandíbula izquierda. e) Fila de "ganchos cefálicos" observados con microscopia de luz y barrido. 


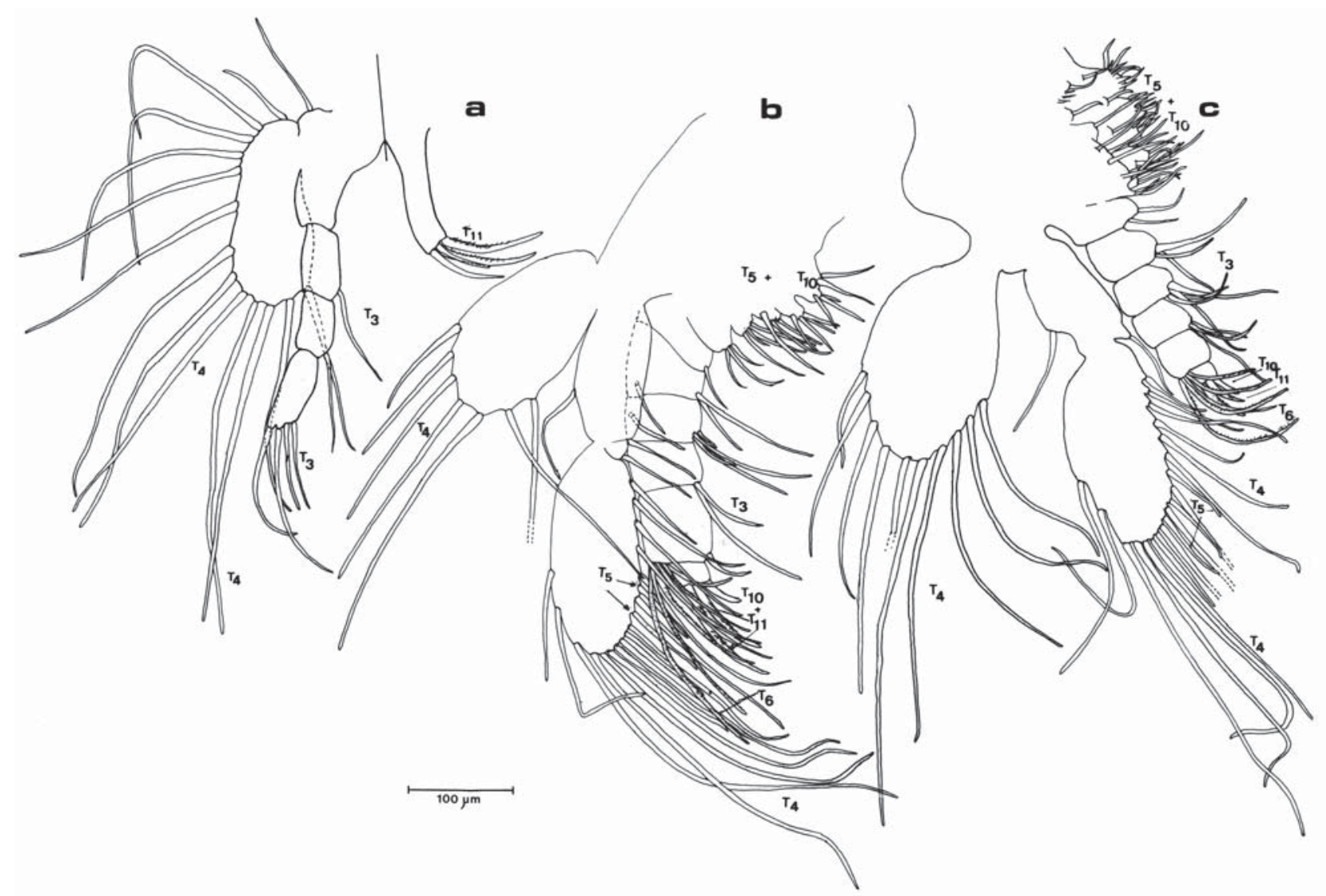

Figure 3. Appendages and setae in Sandersiella chilenica sp.nov. (dissected specimen). a) First right maxilla. b) Second right maxilla. c) Fifth right thoracopod.

Figura 3. Apéndices y setas en Sandersiella chilenica sp. nov. (ejemplar disectado). a) Primera maxila derecha. b) Segunda maxila derecha. c) Quinto toracópodo derecho

Thoracopods. (Figs. 3 c, 4 a-e. Pls. 1 A, J; 2 G; 3 A, B). First 5 limbs similar to each other and to maxilla 2; only the relative size of their articles and setation differs slightly (Table 2). Protopod having 6 endites less clearly differentiated than in maxilla 2 , but with setae and spines covering somewhat wider areas. Endopod of thoracopod 5 (Fig 3 c) shorter than in former limbs; podomeres 1-4 subequal in size, with a medial low bulge carrying plumose setae $\left(\mathrm{T}_{3}\right)$; only 5 lateral serrate setae $\left(\mathrm{T}_{6}\right)$ on fifth podomere. Pseudepipod (exite) distally rounded. Endopod of thoracopod 6 (Fig. 4 a) as on preceding limb, but with a medio-distal plumose seta on its fifth segment. Pseudepipod slender, about 2 times longer than broad; lateral (external) margin convex, somewhat angular; medial (inner) margin smoothly curved; distal slightly tapered. Lateral process on proximal exopodal podomere short, with broad base and a dome-like, slightly angular outline. Distal exopodal podomere, with external margin broadly rounded; distal end divided into a short, slightly truncated lateral lobe and a flat medial portion whose margin is approximately normal to the long axis of segment. Lateral lobe with 4 long plumose-serrate setae $\left(\mathrm{T}_{4}\right)$; its medial portion with 5 shorter ones, and with a long finger-like process on its anterior face.

Endites of thoracopod 7 (Fig. 4 b. Pls. 1 J; 2 G) with a much reduced number of spines and setae. Endopod slightly shorter and narrower than on preceding limb and slightly curved medially; podomere 1 coalesced with the protopod and carrying 1 plumose seta $\left(\mathrm{T}_{3}\right)$; podomeres $2-4$ armed with two medial plumose setae, one of them becoming very small on segment 4; podomere 5, 1.2 times longer than wide, armed with only one lateral serrate seta but without a medial one; podomere 6 surmounted by a slender, straight $\left(\mathrm{T}_{5}\right)$ seta and a short thick claw-like seta $\left(\mathrm{T}_{11}\right)$ with rounded tip. Proximal exopodal podomere with 2 lateral setae; distal podomere with only 15 plumose-serrate setae $\left(\mathrm{T}_{4}\right)$. Pseudepipod with distinctly concave medial margin (appearing to be bent downwards), widest on distal half, broadly rounded distally; with 7 plumose-serrate setae $\left(\mathrm{T}_{4}\right)$. 


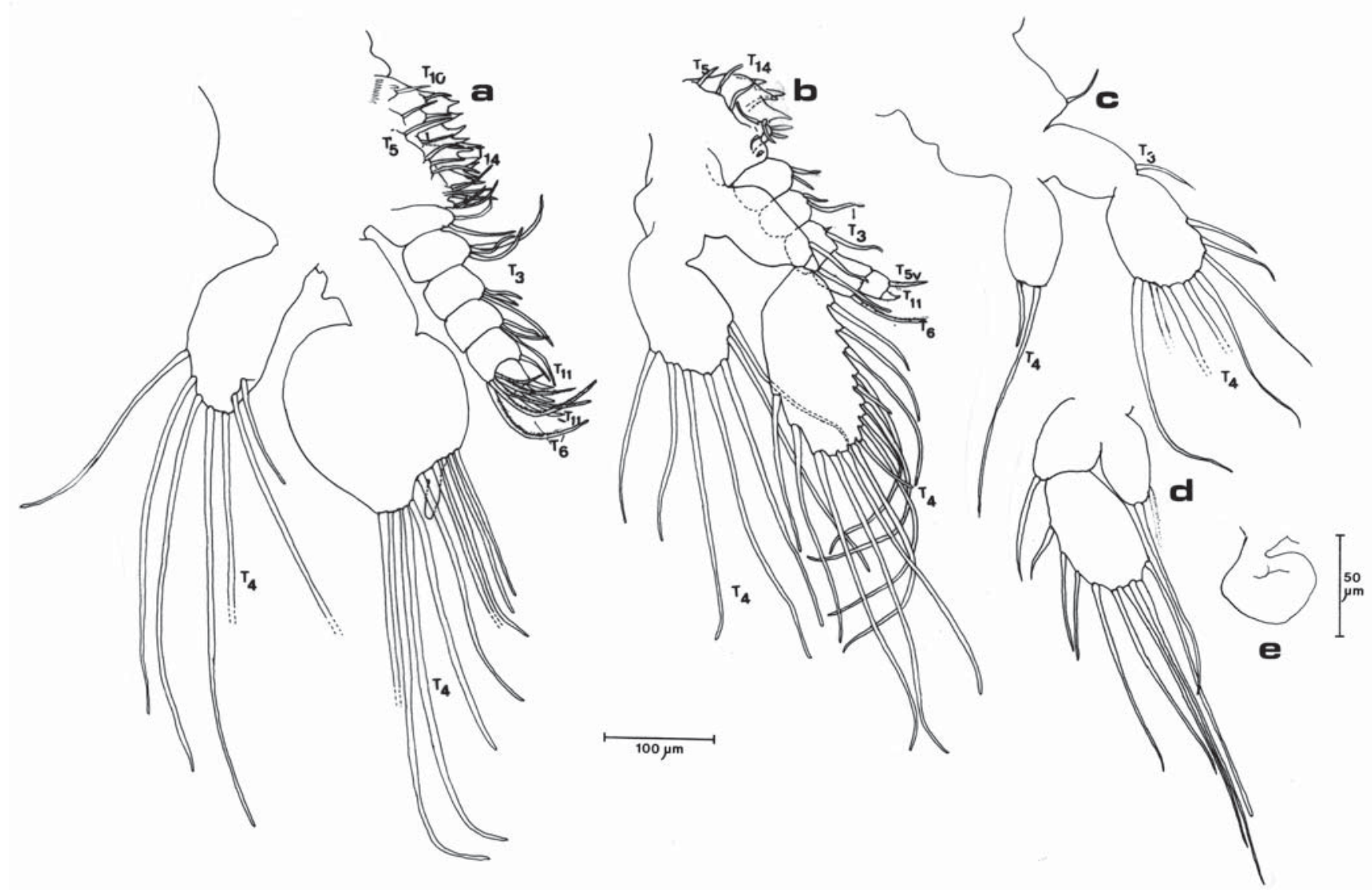

Figure 4. Appendages and setae in Sandersiella chilenica sp.nov. (dissected specimen). a) Sixth right thoracopod. b) Seventh right thoracopod. c) Eigth right thoracopod. d) Eigth left thoracopod. e) Ninth right thoracopod.

Figura 4. Apéndices y setas en Sandersiella chilenica sp.nov. (espécimen disectado). a) Sexto toracópodo derecho. b) Séptimo toracópodo derecho. c) Octavo toracópodo derecho. d) Octavo toracópodo izquierdo. e) Noveno toracópodo derecho.

TABLE 1. Comparative counts of setae on the 19 exopodal segments of antenna 2 for the known species of Sandersiella. Only the first and the last seven segments show equivalency $(\mathbf{x}=$ total $)\left({ }^{1}\right.$ Shiino, $1965 ;{ }^{2}$ Shimomura y Akiyama, 2008).

TABLa 1. Recuento comparativo de setas en los 19 segmentos del exopodo de la antena 2 para las especies conocidas de Sandersiella. Sólo el primer segmento y los últimos siete muestran equivalencia $(\mathbf{x}=$ total $)\left({ }^{1}\right.$ Shiino $1965 ;{ }^{2}$ Shimomura y Akiyama 2008).

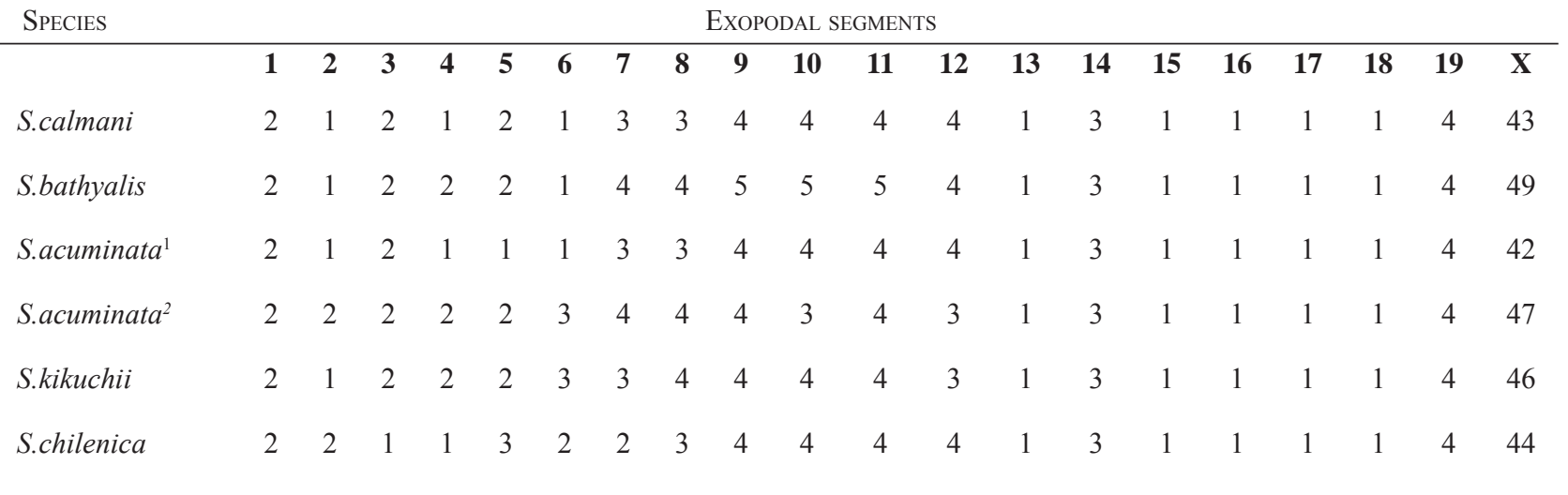


TABLE 2. Number of setae on the endopodal and exopodal segments and pseudepipod of the maxillae and thoracopods of the 5 known species of Sandersiella. (Partly compiled from Hessler and Sanders 1973). Undescribed setae might be counted on the figures given by these and other authors, although it may be that not all have been illustrated (dashes and blank spaces). ( ${ }^{1}$ Shiino, $1965 ;{ }^{2}$ Shimomura \& Akiyama, 2008).

TABLa 2. Número de setas en los segmentos exo- y endopodales y el pseudoepipodio de las maxilas y toracópodos de las 5 especies de Sandersiella (Compilado en parte de Hessler y Sanders 1973). Las setas no descritas se pueden contar en las figuras de estos autores, aunque es posible que no todas hayan sido ilustradas (guión y espacios en blanco). ( ${ }^{1}$ Shiino $1965 ;{ }^{2}$ Shimomura y Akiyama 2008).

\begin{tabular}{|c|c|c|c|c|c|c|c|c|c|c|c|}
\hline \multirow[b]{3}{*}{ Setae and claws: } & \multicolumn{6}{|c|}{ Endopodal segments } & \multicolumn{4}{|c|}{ Exopodal segments } & \multirow[t]{3}{*}{ Pseudepipod } \\
\hline & \multirow[t]{2}{*}{1} & \multirow[t]{2}{*}{2} & \multirow[t]{2}{*}{3} & \multirow[t]{2}{*}{4} & \multicolumn{2}{|c|}{5} & \multirow{2}{*}{$\begin{array}{c}6 \\
\text { claws }\end{array}$} & \multicolumn{2}{|l|}{1} & \multirow[t]{2}{*}{2} & \\
\hline & & & & & medial & lateral & & medial & latera & & \\
\hline \multicolumn{12}{|l|}{ First maxilla } \\
\hline S. acuminata ${ }^{l}$ & - & 2 & 1 & 4 & - & - & - & - & - & $8-9$ & - \\
\hline S. acuminata ${ }^{2}$ & & 1 & 1 & 4 & & & & & & 10 & \\
\hline S. calmani & $?$ & $?$ & $?$ & $?$ & - & - & - & - & - & 9 & - \\
\hline S. bathyalis & $?$ & $?$ & $?$ & $?$ & - & - & - & - & - & 14 & - \\
\hline S. kikuchii & - & 1 & 2 & 4 & & & & & & $11 ?$ & \\
\hline S. chilenica sp.nov. & - & 1 & 1 & 4 & - & - & - & - & - & 13 & - \\
\hline \multicolumn{12}{|l|}{ Second maxilla } \\
\hline S. acuminata & 1 & 3 & 4 & 2 & & 4 & 3 & 4 & 1 & $16-19$ & $5-9$ \\
\hline S. calmani & $?$ & $?$ & $?$ & $?$ & & 4 & 3 & $?$ & $?$ & 16 & 8 \\
\hline S. bathyalis & $?$ & $?$ & $?$ & $?$ & & 5 & 3 & $?$ & $?$ & 24 & 10 \\
\hline S. kikuchii & 1 & 2 & $2-3$ & 2 & $0-1$ & $3-4$ & 3 & $4-5$ & 1 & 20 & $7-8$ \\
\hline S. chilenica sp.nov. & 1 & 2 & 3 & 3 & 1 & 6 & 3 & 4 & 1 & $18-19$ & 7 \\
\hline \multicolumn{12}{|l|}{ Fifth thoracopod } \\
\hline S. acuminata & 3 & 3 & 3 & 3 & - & 3 & 4 & 2 & 1 & $18-19$ & $7-8$ \\
\hline S. calmani & $?$ & $?$ & $?$ & $?$ & & 4 & 3 & $?$ & $?$ & 17 & 9 \\
\hline S. bathyalis & $?$ & $?$ & $?$ & $?$ & & 4 & 3 & $?$ & $?$ & 23 & 13 \\
\hline S.kikuchii & - & $2-3$ & $1-3$ & $2-3$ & 1 & 3 & 3 & $1-2$ & 1 & $20-23$ & $8-9$ \\
\hline S.chilenica sp.nov. & 2 & 3 & 4 & 3 & $0-1$ & 5 & 3 & $1-2$ & 1 & 19 & 10 \\
\hline \multicolumn{12}{|l|}{ Sixth thoracopod } \\
\hline S. acuminata & 2 & 2 & 3 & 2 & - & 2 & 2 & 1 & 9 & 9 & $6-7$ \\
\hline S. calmani & $?$ & $?$ & $?$ & $?$ & & 2 & 2 & $?$ & $?$ & 9 & 6 \\
\hline S. bathyalis & $?$ & $?$ & $?$ & $?$ & & 5 & 2 & $?$ & $?$ & 9 & 7 \\
\hline S. kikuchii & - & $2-3$ & $3-4$ & 3 & $0-1$ & 3 & 2 & $1-2$ & 0 & 9 & 7 \\
\hline S. chilenica.sp.nov. & 2 & 3 & $3-4$ & 3 & 1 & 5 & 3 & $0-2$ & - & 9 & 7 \\
\hline \multicolumn{12}{|l|}{ Seventh thoracopod } \\
\hline S. acuminata & - & 1 & 1 & 1 & - & $1-2$ & & 2 & - & $11-13$ & 4 \\
\hline S. calmani & - & 2 & 2 & 1 & - & 1 & & 2 & - & 11 & 6 \\
\hline S. bathyalis & 1 & 2 & 2 & 2 & - & 1 & & 2 & - & 19 & 10 \\
\hline S. kikuchii & - & 2 & $2-3$ & $1-2$ & 0 & 1 & 2 & 2 & 0 & $14-17$ & $5-6$ \\
\hline S. chilenica sp.nov. & $1-2$ & 2 & 2 & 2 & $0-1$ & 1 & $1+1$ & 2 & - & 15 & 7 \\
\hline \multicolumn{12}{|l|}{ Eighth thoracopod } \\
\hline S. acuminata & & & & & & & & 1 & & $6-7$ & 1 \\
\hline S. calmani & & & & & & & & 2 & & 6 & 1 \\
\hline S. bathyalis & & & & & & & & 1 & & 11 & 1 \\
\hline S. kikuchii & & & & & & & & 2 & 0 & $8-10$ & $2-3$ \\
\hline S. chilenica sp.nov. & & & & & & & & 2 & & 8 & 1 \\
\hline
\end{tabular}


Exopodal distal podomere of thoracopod 8 (Fig. 4 c. P1. $1 \mathrm{~J})$ large, 1.5 times longer than proximal one, with 8 plumose-serrate setae $\left(\mathrm{T}_{4}\right)$; distal third of lateral margin rounded; medial margin of exopodal proximal podomere convex, with one distal plumose seta $\left(\mathrm{T}_{3}\right)$.

Pseudepipod oval elongated with only one short seta and a distal plumose-serrate seta $\left(\mathrm{T}_{4}\right)$. For comparative setal count of thoracopods 5-8, in Sandersiella species, see Table 2.

\section{DISCUSSION}

\section{TAXONOMIC AND OTHER DIAgNOSTIC FEATURES}

a) Setules AND DENTICles

The concept of setule for the group was first introduced by Sanders $(1957,1963)$ in the description of the "small stiff setules" forming the "pretelsonic comb" in H. macracantha and used later for the same structure by Shiino (1965) in the description of Sandersiella acuminata, and by Knox \& Farwick (1977) in Chiltoniella elongata. However, the description of setal characteristics in higher Crustacea has validated this name to describe secondary outgrowths on the shaft of setae with an articulation in the socket area which, as described by Garm (2004), may harden to become denticles "with no articulated socket", a common transition also observed in $S$. chilenica sp.nov. on the shaft of the larger setae (Pl. 1 E, G, H; Pl. 3 A, B).

Nevertheless, the name "setule" has also been used in the Cephalocarida to describe linear arrangements of dense cuticular outgrowths smaller than setae, accurately represented and illustrated in the maxillae and thoracopods of H. brasiliensis and S. kikuchii. Such designation can be validated only if they do not have terminal o subterminal pores or else, to be considered "short setae", if they have them. In fact, Hessler \& Wakabara (2000) have called attention to the common presence of setules and fields of minute spines on the exites of $H$. brasiliensis and shown in the literature to be present on appendages of H. macracantha (Sanders, 1957), Lightiella serendipita (Jones, 1961), L. incisa (Gooding, 1963), L. monnotiae (Cals \& Delamare Deboutteville,1970) and Chiltoniella elongata (Knox \& Fenwick, 1977). But, warning that as these structures are easily overlooked and where noted, it is likely that they are included inconsistently, conclude that "accurate distributional comparisons are not possible". This is undoubtedly true, and further attention should be given to their presence or absence in different species and to their accurate illustration, as aside of having a functional role they may have taxonomic value, as well. Regarding the genus and species of Sandersiella, they can be observed in the drawings of S. kikuchii (Shimomura \& Akiyama 2008), but are not mentioned nor figured for appendages in the original description of S. acuminata (Shiino 1965), its redescription (Shimomura \& Akiyama 2008); nor in $S$. calmani and S. bathyalis (Hessler \& Sanders, 1973). They are neither present in S. chilenica sp.nov.

Equally relevant to this discussion is the important observation by Hessler \& Sanders (1964) of consistent differences between specimens of $H$. macracantha in 300 meters, off Marha's Vineyard, Massachusetts, and the specimens of this same species collected at depths of 9 to 29 meters at Buzzards Bay and Long Island Sound. The most important were: fewer marginal setae on the distal exopodal segment of all the thoracic limbs and on the pseudepipod of some of the thoracic limbs, and most strikingly, the presence of only two marginal spines on the pseudepipod of the last thoracic limbs, in contrast to the usual four on specimens from Buzzards Bay. Yet, they did not feel that these differences were sufficient to consider these specimens no more than a "variety" of $H$. macracantha, due to its adaptation to a different coarser sediment (83\% sand or coarser). However, such initial (?) morphological adaptation to a new environment may be the usual evolutionary mechanism leading to further morphological differentiation in food selection and behavior facing a new niche.

b) Setae And Sines of the ENDites AND the Ventral FOOD GROOVE

The so-called "ventral food grove" first named and described by Sanders (1963: 9. Figs: 3, 4,6) for H. macracantha is an important, externally delimited space of the anatomy of all Cephalocarida affecting and characterizing the anteroventral part of the body and its appendages, as well (Pl. 1, A). We repeat here Sanders' diagnosis as differences in species habitat may correspond to the differences in armature found in ventral appendages.

"The "ventral food groove" extends along the midventral surface of the thorax and posterior cephalon. In the thoracic region this groove is bounded ventrally by the dorsal surface of the proximal endites and laterally and ventrally by the protopod. The dorsal boundary is a series of smooth, convex invaginations of the body wall, one per segment, caused by the protuberance of the ventral nerve cord ganglia. The food groove is shallowest at the midpoint of the trunk segment and deepest at the anterior, posterior and lateral margins. Between the limb bases, the food groove is confluent laterally with interlimb spaces. At the level of the trunk limbs seven and eight, it is flattened and shallow. In the region of the second maxilla and the posterior extension of the labrum, the groove is convex; two shallow ridges, the paragnaths, appear near the lateral edges of the food groove. The paragnaths are more prononunced anteriorly; there the convexity of the food groove is deeper. At the level of the first maxilla, the convexity is V-shaped. The 
food groove is deepest between the insertion of the first maxilla and mandible; afterwhich it becomes shallow, and then disappears anterior to the mandible". Endites and their spines undoubtedly play a fundamental role in dislodging and transporting forward the material suspended. The whole sequence was filmed and masterly described by Sanders (1963) as functional morphology.

c) TEM AND OTHER EXTERNAL MORPHOLOGICAL CHARACTERISTICS Elofsson \& Hessler $(1991,1994)$ introduced some new features in the description of the external morphological characteristics of this group, by describing microscopic external "cushions", hairlike scales, small setae, and pores as cuticular outgrowths in H. macracantha. Similar but not all identical structures are found in S. chilenica sp.nov. (and probably in the other genera of the family) as discussed below.

A microsculpture of "packed cushions" ornamenting the surface of the body cuticle, only observable under SEM, seems to be a general feature for all Cephalocarida. According to the observations reported for H. macracantha, this is the only ornamentation on the head-shield, and the abdominal segments (Elofsson \& Hessler 1994, Figs.1 and 2). A similar sculpture is observed on S. chilenica sp. nov., but also present on the ventral part of the cephalon, the toraxic and abdominal segments, and even the caudal rami (Pl. 2, D, F; Pl. 3, D, E). Three other types of cuticular ornamentation identified as scales, setae and, pores, were also described by Elofsson \& Hessler $(1991,1994)$ for the two antennae and the thoracic and abdominal segments in H. macracantha.

A "sparse ornamentation in the form of thin scales" was found on the setae of the two antennae in H. macracantha (op. cit. 1991:347). No figures of such scales were shown but we believe they refer to the setules found on the setae of S. chilenica sp.nov. and other species of Cephalocarida, and in fact, in all Crustacea. Two other types of "scales" were found later on the thoracic and abdominal segments of $H$. macracantha (op.cit.1994:455): stout and straight "hairlike scales", located along the margins of the polygonal fields, and slightly larger, slender, "terminally hooked scales" within the polygonal fields of the abdomen (op. cit., Fig.2). No such thin scales are found over the setae of the two antennae and the body of $S$. chilenica sp.nov. As already described, there are many small (hair-like) setae over its body, many a bit longer with its end bent, but only isolated setules on some of the large setae may show this so called "scaly" modification. On the other hand, hardening of the cuticle in small setae to become small spines as already mentioned, is a common process first noticed by Sanders (1963: 7, Fig.2), in the fusion of the "setules" or small setae he described forming the "teeth" of the caudal combs (our Plate 3, G,H).
In addition, two peculiar types of setae were also described (Elofsson \& Hessler, 1994, Figs. 1, 2), distributed all over the headshield, on the tergum and pleurae of the thoracic segments, and ventrally arranged along the caudal margin. A simple one, thin and cylindrical, with an apical pore of the same diameter, and a thicker one, widening from a cylindrical base and then becoming thinner to end with a large slit looking opening (op.cit., Fig. 2). A variable number of setae on adjacent thoracic and abdominal segments is mentioned. They seem to be equivalent to our setae of type 9, with terminal pore found growing out of large pits, or close to the bilobed valve-like openings emerging out of the epidermis.

Finally, two types of pores were also recognized on Hutchinsoniella's body (op.cit.,1994; Figs. 1, 2): a simple one which formed a hole $(0.5-0.7 \mu \mathrm{m})$ in the cuticle with a cilium hardly reaching out of the opening; and a larger one (approx. $3 \mu \mathrm{m}$; inset in Fig. 1) forming a diaphragm shaped as a moat with a central tower that carries the opening (inset in their Fig. 1). In general, Elofsson \& Hessler ( $o p$ cit.) comment that "setae and pores were found all over the body except for endopods of the legs", adding that "they are rare on the exopods and epipods and sparse on the ventral surface of the thorax and headshield". Pending ultrastructural studies it is not clear to us whether these "pores" are equivalent to the "pits" and setae found in $S$. chilenica sp.nov.

\section{d) Other diagnostic Features}

The characterization of some other morphologial structures used as diagnostic features to differentiate species, requires clarification. The ventral row of the so-called "hooks", found on both sides under the antero-lateral margin of the cephalon, is considered a diagnostic feature for species of the genus Sandersiella, except for S. bathyalis Hessler \& Sanders, 1973. They are also reported for Hampsonellus brasiliensis Hessler \& Wakabara, 2000 and recently Shimomura \& Akayama (2008) describing them in the new species Sandersiella kikuchii concluded that although the number of "hooks" shows considerable variation they are useful for discrimination "of the 4 species" (referring to S.acuminata, S.calmani, S.bathyalis, and S kikuchii).

Light microscopy drawings show the profile of these "hooks" laterally positioned at the anterior ventral border of the cephalon, with the cusps pointing forwards. But, this seems to be a misinterpretation as SEM observations in the new species (Pl. 2, C ) show no "hooks" but rather a "truss" of strong supporting membranes without cusps, like "roof rafters", possibly to prevent collapsing of the latero-frontal parts of the cephalon, but facilitating its complex movements (Sanders 1963, Figs.12,13). 
In describing $S$. acuminata Shiino (1965) mentioned a "double row" of these structures. In the new species, however, an apparent double row is observed only in moulting specimens, as also illustrated by Hessler \& Sanders (1973, Fig. 2 B) for $S$. calmani. The same observation applies to the double row of "spinules" and "tiny setules" described for S.acuminata on the caudo-sternal (disto-ventral) border by Shiino (1965) accurately figured by Hessler \& Sanders (1973, 2HB) as only one row. S.chilenica sp.nov. also presents an apparent double row only in moulting individuals.

Elofsson \& Hessler (1991) studied the ultrastructure of the first and second antenna of Hitchinsoniella macracanta, describing their external morphology as well. Regarding the setae found on both appendages, they conclude that all are built according to the same plan... "with sizes varying between more than $200 \mu \mathrm{m}$ and less than $100 \mu \mathrm{m}$ in length, with their distal part showing internal circular furrows in the inner wall..." (1999, Fig. 6). They did not add, however, that the internal furrows are also observable externally as annuli, as seen in their Figure 3. In fact, externally annulated setae in antennae 1 have been described in Sandersiella (Shiino, 1965; Wakabara, 1970) and Lighthiella ( Jones, 1961) and they are also clearly present in the setae of antennae 1 and 2 in Sandersiella chilenica sp.nov. (Pl. 1, G). Other coincident and numerous cuticular outgrowths, usually referred to as "setules" in the literature (see former discussion), are mentioned which in the case of the antennae of $H$. macracantha the same authors simply identify as "thin scales... with sparse distribution", without any further morphological characterization.

Another important feature present on the first antenna of the new species is the long aesthetasc. Originally not described for other species of the genus either because the description of the first antenna is missing ( S.calmani and S.bathyalis), or it was not differentiated as such (S.acuminata), it is now known to be present in all Cephalocarida, although it can easily break, commonly resulting in sorted specimens with only the base of the long annulated structure. In fact, aesthetascs of the new species greatly resemble those of Hutchinsoniella drawn originally but described under another name ( Sanders, 1957, "strap-shaped filamentous portion of about 35 joints", Fig. 1 A) and Lightiella (Jones, 1961, "filamentous structure composed of many joints", Fig. 5). Regarding this appendage we have also been able to confirm Hessler \& Sanders generic remark (1973:182) that the peduncle of the first antenna is two-segmented.

In the comparison of the ultrastructure of the aesthetasc in $H$. macracantha with the setae found on antenna 1, Elofsson \& Hessler (op.cit.) gave its measurement as of more than 300 $\mu \mathrm{m}$ in length and $3 \mu \mathrm{m}$ in diameter for most of its length. In the new species we measured longitudes ranging between 400 and $800 \mu \mathrm{m}$. Comparing its general characteristics with those of around other 100 setae found in the two antennae, these authors wonder why the potential demand of greater compensatory information in a blind animal such as Hutchinsoniella and the Cephalocarids in general is not expressed in a more strongly developed antennal armament, concluding that ..."either augmented chemical information is not needed, or it is at least not manifested in the development of sensilla of the first antenna". However, we believe that the setae in the two antennae do present a "better armament" in the enormous amount of setules found in the combined number of long and short setae present on each of the two antennae and other appendages as here described. The large number of setules (apparently some with pores ) found on some setae and denticles present on others, very possibly conveying chemical and mechanical information, could help to explain the complexity of the brain described by Elofsson \& Hessler (1990) and particularly its behavior, known already for Hutichinsoniella macracantha after the pioneering and unique study of its functional morphology by Sanders (1963: 9-13, Figs 1-13).

Enlargements obtained with SEM permit the differentiation of such external morphological details otherwise barely or insufficiently noticed under light microscopy. Among other characteristics, the covering of the body and appendages by small setae, denticles and spines already described, undoubtedly serve sensorial and mechanical function. For instance, they are notorious on the exopod of the second antenna where fringing small spines ("stiff setules" of various authors) are clearly differentiated from simple setae. They have been recorded for different species of Sandersiella from annuli 14-18 (S. bathyalis), 17-18 (S. calmani ), 15-18 (S. acuminata) and 12-18 in S.kikuchii, but in S. chilenica $s p$. nov. they are present on all annuli. Unfortunately, the first antenna was not mentioned in the original descriptions of S.bathyalis and S.calmani by Hessler \& Sanders (1973), as the recent discovery of S.kikuchii and the redescription of $S$ acuminata Shiino, 1965 ( Shimomura \& Akiyama, 2008) reporting two aesthetascs for each of these two species, against only one observed in S.chilenica sp.nov. and, in fact, in all the remaining genera and species of Cephalocarida known, demands a revision of the presence of this unique chemoreceptive seta on the antenna 1 of the five species assigned to the genus Sandersiella and eventually of the status of this genus.

From these and other diagnostic features given in our description, S. chilenica sp.nov. can be easily differentiated from the other 4 known species of the genus by a combination of the following main characteristics:

a) It has a greater maximal length (caudal rami excluded) than the other 3 species, as we have measured individuals 
of up to $4.3 \mathrm{~mm}$ with an average of $3.3 \mathrm{~mm}$ for 15 specimens.

b) The abdominal pleurae on the second half of the abdomen become as long as wide, while in all the other species are wider than long.

c) The caudal rami are shorter and proportionally thicker than in the remaining species.

d) There are two spinose processes on the dorsal caudal margin (as in Lightiella). Either none of the other species shows this character, or it remains undescribed.

e) The telsonic comb is narrow ( $0.46 \%$ of telson width), but evenly concave.

f) The protopod of maxilla 1 has a disto-lateral seta near its insertion with the exopod. None of the other species show this character or it remains undescribed.

g) The second podomere of the exopod of thoracopod 6, is orbicular and shows a rather long "finger-like process" on its distal anterior face, feature shared only with S.bathyalis and S. acuminata. Such slender projection was not described for $S$. calmani and it is not present in S. kikuchii.

h) There are fringing small spines (stiff setules) on all exopodal annuli of antenna 2 .

Other differences, expressed as number of setae on the appendages, are shown comparatively in tables 1,2 , and 3 . Our observations make also necessary to further modify the following diagnostic features of the genus, listed by Hessler \& Sanders (1973):

- Distal endopodal segment of fifth thoracopod may have 2-4 claws; sixth and seventh thoracopod with 2-3.

- Pseudepipod of first five thoracopods with 7-10 setae.

- Caudal rami short or long being 1.1 -2.1 times longer than width of telson.

\section{D) Functional REMARKS}

Present work on the function of various types of setae in higher Crustacea advocates the combined use of ultrastructural and physiological studies, as differentiation of mechanoreceptoral or chemoreceptoral properties cannot be ascertained otherwise (Ache 1982, Altner et al. 1983, Hamilton 1983, Laverack \& Barrientos 1985, Felgenhauer 1991, Elofsson \& Hessler 1991, 1994; Garm 2004). Typological differentiation is obviously not sufficient to draw either homologies or analogies, particularly in unrelated groups such as Cephalocarida and higher Crustacea. However, the search and use of a standardized nomenclature is advisable and should be followed by anatomical work using histological, histochemical and ultrastructural methods, plus new TEM techniques to explore detailed internal anatomical aspects of such minute animals. This should be done in the case of the lateral concentration of setae found along the pleural borders, here referred as "lateral line", not described by
Elofsson \& Hessler (1994) in H. macracantha, and in fact in all setae, as well.

Although size is an outstanding handicap for such studies, behavioral studies can throw considerable light on the functional properties of external structures in small crustaceans, as demonstrated for $H$. macracantha by Sanders (1963: 9-13).

From the distribution of the different setae and spines per appendage ( Table 3), and the above discussion of the "ventral food groove" it was inferred that certain types are found only on certain appendages. On the other hand, there seems to be one generalized type of seta (Type 8) and one spine (Type 12) found on most parts of the body. Acknowledging the accurate description of the functional properties of the appendages given by Sanders (1963), our characterization of setae and spines in S.chilenica sp.nov. supports his functional interpretations. Thus, given the general body properties of the cephalocarids, we assume that the appendages in the new species (with the possible exception of the endopod in thoracopod 6) function in the following same way:

a) Antennae 1 and 2 participate in locomotion, food detecting and food gathering. Antenna 1 carries the unique aesthetasc and both antenna 1 and 2, the equally distinct seta of type 2, not found on a ny other appendage.

b) Each maxilla 1 clear spaces anterior to the labrum and at the base of the two pairs of antennae, pushing detrital particles to the mouth. Coincidentally, here appear for the first time the plumose setal types 3 and 4 to retain particles, and setal types 10 and 11 for final dislodging and directing food particles to the mouth.

c) Each maxilla 2 and the thoracopods produce inflowing feeding currents with metachronal movements of locomotion, retaining, dislodging and transporting detrital material forward and dorsally along the ventral food groove, although grinding seems to be the main function of the teeth-like setal modifications of the gnathobases $\left(\mathrm{T}_{10}, \mathrm{~T}_{14}\right)$ and endites. $\left(\mathrm{T}_{6}, \mathrm{~T}_{10}, \mathrm{~T}_{11}\right)$ of thoracopods 5,6 and particularly 7 .

d) Telsonic and pretelsonic combs and the setae of the caudal rami are used in grooming to clear the head and trunk appendages and the food groove (see Sanders, 1963 for detailed description and figures).

Accordingly, we suggest that the aesthetasc, traditionally considered and demonstrated to be sensorial in function and, in particular, setal type 2, combine the functional properties summarized in a). The different size and disposition of the setules, primarily suggest sensorial properties. The groups of setal types 3-6, identified with b) and c) above, have common structural properties suggesting their use in food gathering and food transfer, and possibly in food detection, as well. The spine-like setal types 10 and 11 (and 
type 6, as well) seem to participate in abrading as much as in dislodging detrital material. Consequently, if all these types are differentiated as in the figures 3 to 7 of Sanders (1963), their functional properties become largely clarified. Undoubtedly, further histological and ultrastructural studies will elucidate these properties.

Regarding reproduction, and considering the similarities observed in all the Cephalocarida known, Hessler and Wakabara (2000) have concluded that in the lack of contrary evidence, Cephalocarids may be all simultaneous hermaphrodites. They further suggest that, although oviposition has never been observed, it is likely that the egg emerging out of the genital pore (on the posterior part of the protopod of thoracopod 6), is directed posteriorly to the ninth reduced thoracopod, where it is cemented in place. Carcupino et al. (2006), follow this interpretation, speculating that the lack of thoracopod 8 in Lighthiella, may facilitate the egg transfer to thoracopod 9. A simplified process would take place in Chiltoniella elongata Knox \& Fenwick, 1977 if indeed bears the genital pore on thoracopod 9. In all cases, the great bending flexibility of the abdomen against the last thoracic segments may also be important to facilitate the cementing of eggs on the reduced thoracopod 9.

\section{E) Ecological REMARKS}

Sanders $(1960,1963)$ detailed pioneering study of $H$. macracantha, combining the description of its habitat and associated community structure of the environment at Buzzard Bay, Massachusetts is the only one of its kind. The species, found from 1-3 $\mathrm{m}$ in mud beneath Zoostera grass and from 6-300m subtidally, was described as ... "wholly confined to soft subtidal sediment of the sticky consolidated grey zone overlaid by a flocculent, brown, unconsolidated layer approximately $2 \mathrm{~cm}$ thick", and living on and in this flocculent zone. Sanders (1963) confirmed this habitat by observations of the material found in the food groove, the fecal pellets and gut, corroborating that the species is a nonselective deposit-feeder since, in all cases, the material was composed of diatoms frustules, a few sand grains, silt particles, and much detritus De Troch et al. (2000) in a detailed study of the meiofauna (defined as Metazoa $3 \mu \mathrm{m}$ to $1 \mathrm{~cm}$ ) in seagrass beds along the Caribbean coast of the Yucatán Peninsula, México, described the microhabitat preferences of Lightiella incisa, a work considered by them as the only detailed study of a cephalocarid niche, corroborating the general conclusions reached by Sanders 1960. They found that $L$. incisa followed polychaetes to deeper sediment layers and characterized it as an endobenthic species occupying anoxic sediments oxygenated by bioturbation and strongly related to nitrite and nitrate concentrations, although total organic matter (TOM) showed only minor variations with depth. The highest density of this species was related to the lowest concentration (of "nitrite/nitrate") with a similar trend for ammonia and silicates. Such fundamental conclusions would have to be tested for open coastal environments considering, as they point out, integrated standardized measurements of oxygen and the RPD-layer.

TABLE 3. Setal types and their distribution on the appendages and other parts of the body of Sandersiella chilenica sp.nov. (* types also found on the endites of gnathobases). See text for explanations, and Figure 1 and plates 1 to 3 for illustrations.

TABLA 3. Tipos de setas y su distribución en los apéndices y otras partes del cuerpo de Sandersiella chilenica sp.nov. (* tipos que también se encuentran sobre los enditos de la gnathobases). Véase el texto para explicaciones, y las figuras 1 y láminas 1 a 3 para ilustraciones.

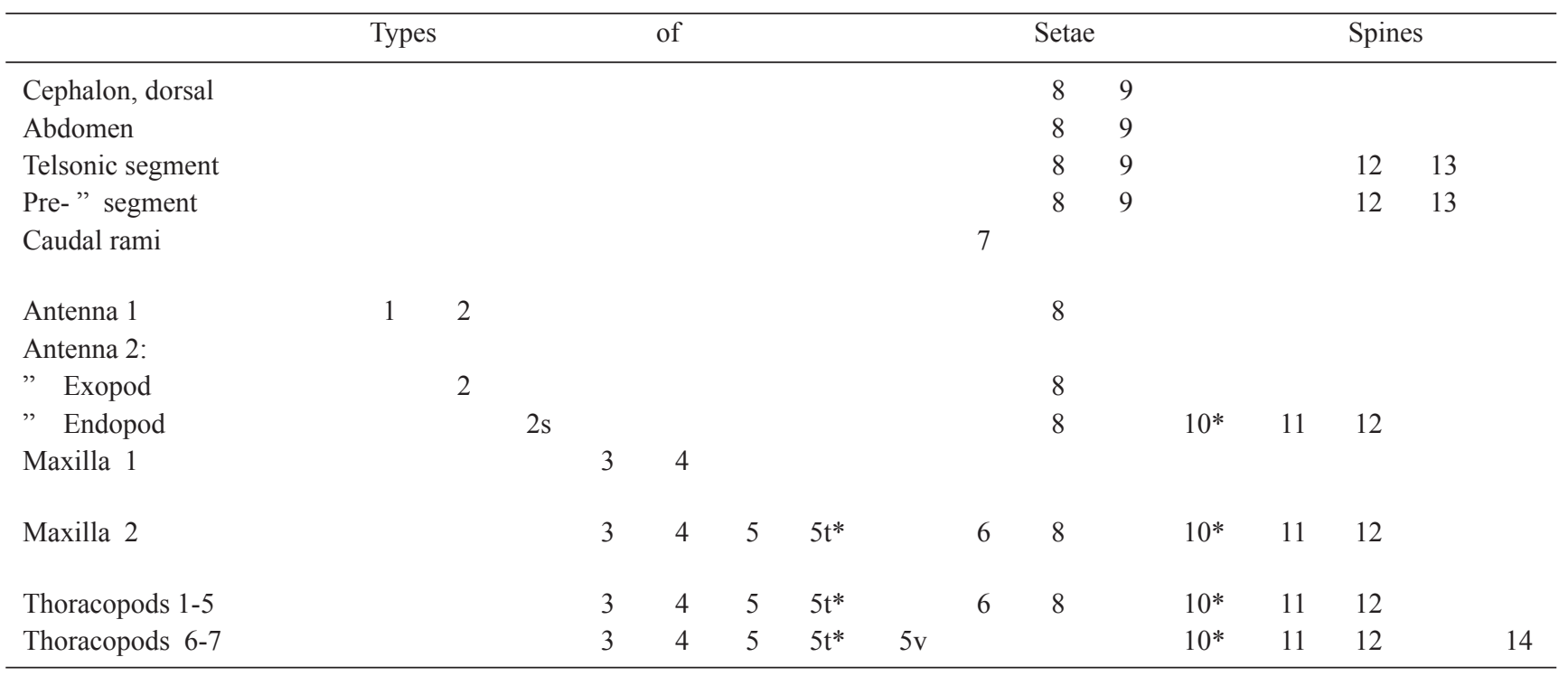


Integumentary structures in Sandersiella chilenica sp. nov.: José R. Stuardo \& René Vega

None such studies have been done on any of the four species now known for the genus Sandersiella. $S$. acuminata from Japan is the only species of the genus found in subtidal muddy bottoms with Zoostera down to $32 \mathrm{~m}$.; S. kikuchii was found at a depth of $300 \mathrm{~m}$ in muddy bottom, off the Boso Peninsula, central coast of Japan; S. bathyalis is a deep water species found off the coast of Walvis Bay, Southwest Africa, in 1546-1559 m, green mud; S. calmani was collected off the south coast of Perú in organic-rich mud, at $85 \mathrm{~m}$ depth; S. chilenica sp.nov. was collected with a bottom grab at Coliumo Bay, central Chile from muddy bottom in 6-10 m depth, with predominance of fine sand, about $37 \%$ of silty-clayed sediments and $4.38 \%$ of organic matter.

Specimens of the new species appeared in low numbers together with the following numerically dominant species: the polychaete Prionospio pinnata, the amphipod Ampelisca araucana, the pea-crab Pinnixa valdiviensis, the mollusks Nassarius gayi, Nucula pisum, Vitrinellidae spp., Malletia chilensis and unidentified Cumacea. Less abundant were
Mysella molinae, Macoma inornata and Callianassa uncinata all inhabitants of muddy bottoms.

Among the polychaetes only the common Prionospio species were identified which in terms of crude estimates of biomass were as abundant as the amphipod Ampelisca araucana. Regarding wet weight, polychaetes rank first with the gastropod Nassarius gayi. Although this bay and the surrounding shelf have been extensively studied and reviewed (Neira \& Palma, 2007), this is the first paper to address the Cephalocarida. Considering the percentage of fine sand to silt-clay, the habitat of $S$. chilenica sp.nov. agrees in general with the sedimentary substrate described for the majority of the species of the group. However, there is no certainty that the species is limited to the flocculent sediment surface or, if as disclosed by De Troch et al. (2000) may live in the burrows of Callianassids, the tubes of Ampelisca araucana, or together with other infaunal members of the association. The study of these associations as well as the distribution of this species along the central and southern coasts of Chile, need to be addressed.

Plate 1. Sandersiella chilenica sp.nov. (SEM observations; $\mathrm{T}=$ setal type; $\mathrm{Th}=$ thoracopod)

A. Ventral view of cephalic and thoracic appendages delimiting the "ventral food groove". Labrum shown between the 2 pairs of antennae. x 64.

B. Ventral view of single left egg on adult specimen, carried on thoracopod 9. Notice the mat of plumose-serrate setae from anterior thoracopods probably providing ventilation and preventing egg abrasion) $\mathrm{x} 56$.

C. Enlarged view of setal type $9\left(\mathrm{~T}_{9}\right)$, on dorsal part of the cephalon. $\mathrm{x} 6000$. See also P1.2,D.

D. Partial view of antenna 2, seen ventrally, showing large setae $\left(\mathrm{T}_{2}\right)$ and fringing rows of small smooth spines on each segment $\left(T_{12}\right)$ and around the base of each seta. To the right, claw-like setae $\left(T_{11}\right)$ and conate seta $\left(T_{10}\right)$ on the endopod of antenna 2 and cover of many small spines $\left(\mathrm{T}_{12}\right)$ on the dorsal part of the endopod. $\mathrm{x} 640$.

E. Claw-like seta $\left(\mathrm{T}_{11}\right)$ bearing denticles on endopod of second maxilla. $\mathrm{x} 1450$.

F. General (ventral) view of left antenna 1, antenna 2 and maxilla 2, showing the long bent aesthetasc $\left(\mathrm{T}_{1}\right)$ and setal types $\mathrm{T}_{2}, \mathrm{~T}_{4}$ and $\mathrm{T}_{5}$. Notice cover of large scales on the exopod of maxilla 2. x 168.

G. Enlarged view of setae of type $\mathrm{T}_{2}$ on antenna 2. Notice setules with apparent terminal pores. $\mathrm{x} 4000$.

H. Plumose-serrate setae $\left(\mathrm{T}_{4}\right)$ with very long lateral setules and short line of central setules becoming denticles. $\mathrm{x} 2000$.

I. Enlarged view of aesthetasc $\left(T_{1}\right)$ showing segments. $T_{12}$ spines in the background. $x 840$.

J. Ventral view of distal podomere and endopod of right thoracopod $7\left(\mathrm{Th}_{7}\right)$ with terminal setae, right thoracopod $8\left(\mathrm{Th}_{8}\right)$ lacking endopod and the reduced right thoracopod $9\left(\mathrm{Th}_{9}\right)$ with lobed structure. Mat of setae of type $4\left(\mathrm{~T}_{4}\right)$ to the right of the picture. x 285 .

Lámina 1. Sandersiella chilenica sp.nov. (microscopia de barrido; $\mathrm{T}=$ tipo de seta; $\mathrm{Th}=$ toracópodo)

A. Vista ventral de los apéndices cefálicos y torácicos delimitando el canal ventral de alimento. Se observa el labrum entre los dos pares de antenas. $\mathrm{x} 64$.

B. Vista ventral en ejemplar adulto, de huevo izquierdo cementado al toracópodo 9. Note la cubierta de setas plumo-aserradas de los toracópodos anteriores que probablemente lo ventilan y protegen. $\mathrm{x} 56$.

C. Vista aumentada de la seta de tipo $9\left(\mathrm{~T}_{9}\right)$ en la parte dorsal del cefalón. x 6000. Véase también lámina 2,D.

D. Vista parcial de la antena 2 en vista ventral, para mostrar una gran seta $\left(\mathrm{T}_{2}\right)$, e hileras basales de pequeñas espinas $\left(\mathrm{T}_{12}\right)$, en cada segmento y alrededor de la base de cada seta. A la derecha, seta ganchuda $\left(\mathrm{T}_{11}\right)$ y seta cuspidada $\left(\mathrm{T}_{10}\right)$, endopodito de la antena 2 y muchas pequeñas espinas $\left(T_{12}\right)$ en la parte dorsal del endopodito. x 640.

E. Seta ganchuda $\left(\mathrm{T}_{11}\right)$ con dentículos, sobre el endopodito de la segunda maxila. x 1450.

F. Vista general (ventral) de la antena 1 izquierda, antena 2 y maxila 2, mostrando el largo estetasco doblado $\left(\mathrm{T}_{1}\right)$ y los tipos de setas $\mathrm{T}_{2}, \mathrm{~T}_{4}$ and $\mathrm{T}_{5}$. Obsérvese la cubierta de grandes escamas sobre el exopodito de la maxila $2 . x 168$.

G. Vista aumentada de la seta de tipo $\mathrm{T}_{2}$ en la antena 2. Se observan sétulas con aparentes poros terminales. $\mathrm{x} 4000$.

H. Seta plumo-aserrada $\left(\mathrm{T}_{4}\right)$ con sétulas laterales muy largas y una corta línea de sétulas centrales transformándose en dentículos. x 2000 .

I. Vista aumentada de estetasco mostrando sus segmentos. Se observan espinas $\left(\mathrm{T}_{12}\right)$ al fondo. $\mathrm{x} 840$.

J. Vista ventral del podomero distal y endopodo del toracópodo derecho $7\left(\mathrm{Th}_{7}\right)$ con setas terminales, toracópodo derecho $8\left(\mathrm{Th}_{8}\right) \sin$ endopodo y el reducido toracópodo $9\left(\mathrm{Th}_{9}\right)$ con su estructura lobulada. A la derecha del cuadro se observan setas de tipo $4\left(\mathrm{~T}_{4}\right)$. 285. 


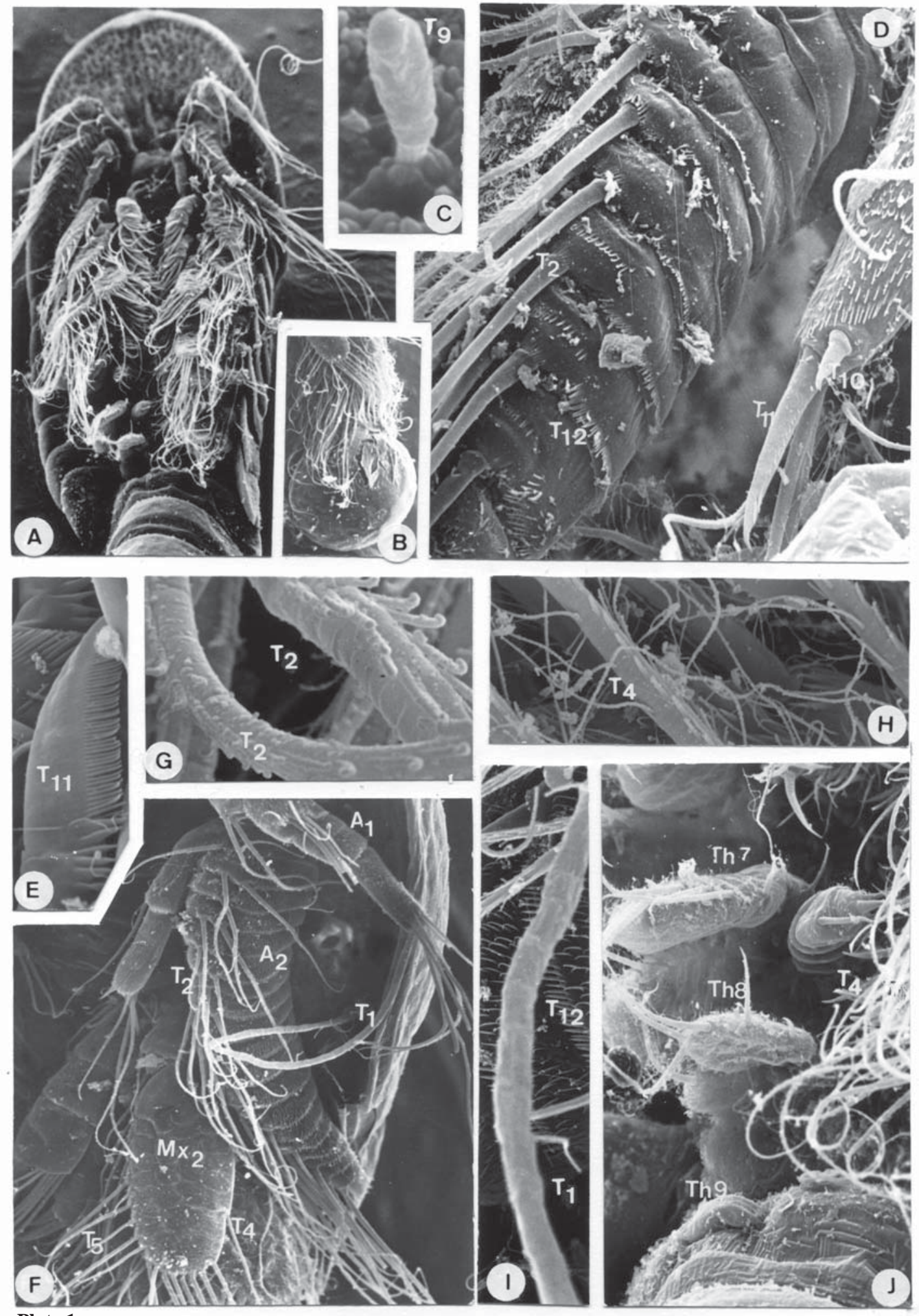

Plate 1. 
Integumentary structures in Sandersiella chilenica sp. nov.: José R. STUARDo \& RENÉ VeGA

Plate 2. Sandersiella chilenica sp.nov. (SEM observations; T= setal type )

A. Dorso-lateral view of the last abdominal segments, showing one dorsal posterior spine (asterisk), the "lateral line" (arrows), the insertion of the pretelsonic and telsonic combs and the left caudal ramus. $x 104$.

B. Conate or spine-like seta $\left(\mathrm{T}_{10}\right)$ on endopod of antenna 2. Notice the lateral slit and basal spines. $\mathrm{x} 6000$.

C. Detail of "hook-looking" folds on the antero-lateral ventral margins of the cephalon. $\mathrm{x} 1520$.

D. Detail of a large seta of Type 9, small setae $\left(\mathrm{T}_{8}\right)$ and the "packed cushions" covering the body cuticle. $\mathrm{x} 4000$.

E. Detail of the overlapping scales covering the external podomere of maxilla 2. $\mathrm{x} 2000$.

F. Patch of large Type 9 setae on the cephalon. $x 200$.

G. Terminal plumose setae $\left(\mathrm{T}_{3}\right)$ on the endopod of maxila 1. x 1300.

H. Squat "spoon-shaped spines" $\left(\mathrm{T}_{14}\right)$, trifid $\left(\mathrm{T}_{5}\right)$ and conate setae $\left(\mathrm{T}_{10}\right)$ found on the endites of thoracopods 6 and 7. (Forms appearing shaded under mat of plumose-serrate $\left(\mathrm{T}_{4}\right)$ and serrate $\left(\mathrm{T}_{6}\right)$ setae, compare plate $\left.3 \mathrm{~B}\right)$. x 1200.

Lámina 2. Sandersiella chilenica sp.nov. (microscopia de barrido; T= tipo de seta )

A. Vista dorso-lateral de los dos últimos segmentos abdominales, mostrando una espina dorsal posterior (asterisco); la "línea lateral" (flechas), la inserción de las "peinetas" pretelsónica y telsónica (con dientes), y la rama caudal izquierda. x 104.

B. Seta tipo cono o espina $\left(\mathrm{T}_{10}\right)$ sobre el endopodo de la antena 2. Note la hendidura lateral y las espinas basales. $\mathrm{x} 6000$.

C. Detalle de los pliegues tradicionalmente considerados "ganchos", bajo los márgenes ventro-antero-laterales del cefalón. x 1520.

D. Detalle de una gran seta de tipo 9 , setas pequeñas simples $\left(\mathrm{T}_{8}\right)$ y los paquetes de gránulos apelmasados que forma la cutícula corporal. x 4000 .

E. Detalle de las escamas sobrepuestas que cubren el podomero externo de la maxila 2. x 2000.

F. Sector sobre el cefalón con grandes setas del tipo 9. x 200.

G. Setas plumosas terminales $\left(\mathrm{T}_{3}\right)$ en el endopodo de la maxila 1. $\mathrm{x} 1300$.

H. Espinas rechonchas con forma de cuchara $\left(\mathrm{T}_{14}\right)$, espina trífida $\left(\mathrm{T}_{5}\right)$ y setas como conos $\left(\mathrm{T}_{10}\right)$ observadas en los enditos de los toracópodos 6 y 7. (Formas sombreadas en la imagen bajo la densa cubierta de setas plumo-aserradas $\left(\mathrm{T}_{4}\right)$ y aserradas $\left(\mathrm{T}_{6}\right)$, compare la lámina 3B) x 1200 . 

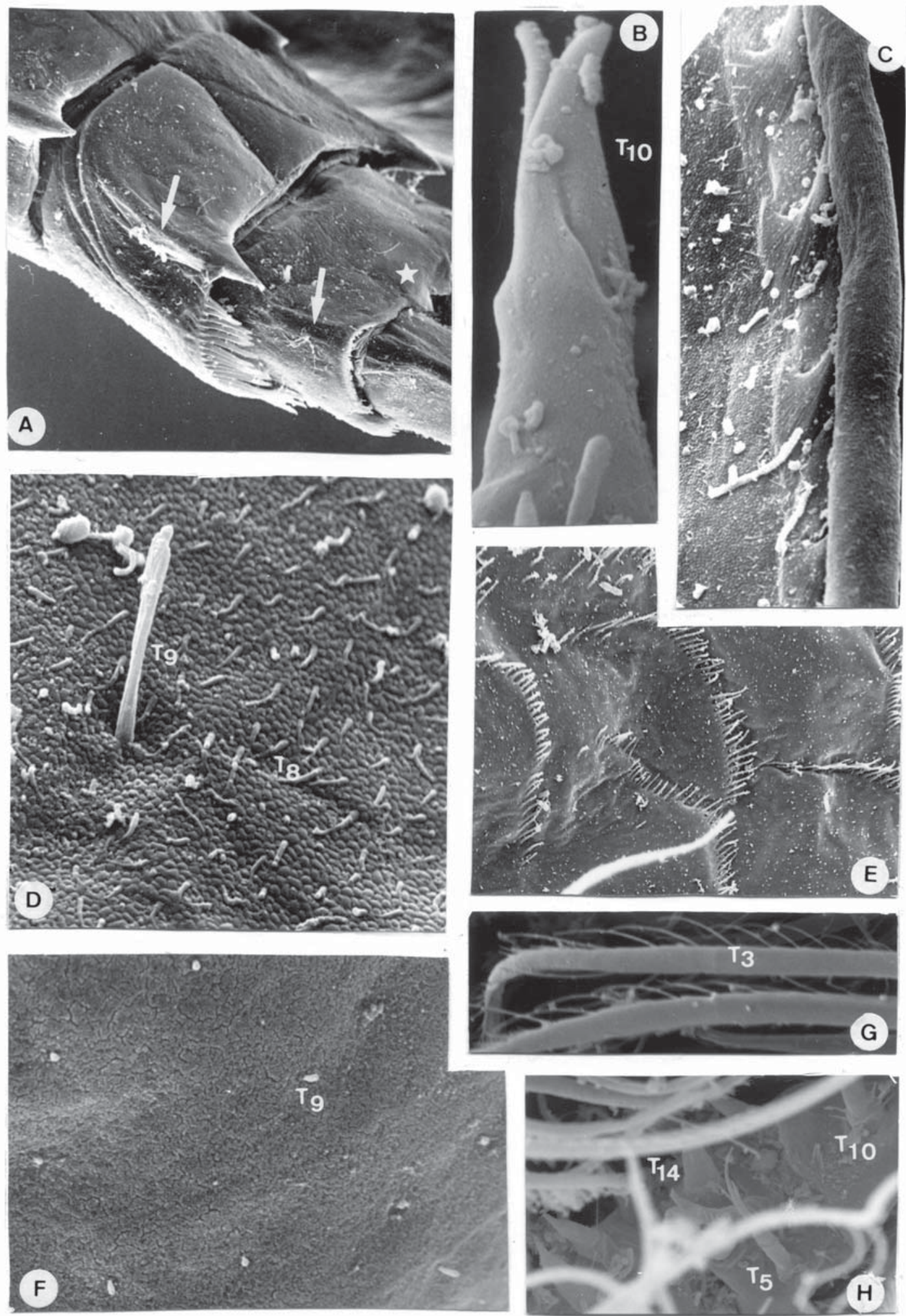

Plate 2. 
Integumentary structures in Sandersiella chilenica sp. nov.: José R. STUARDo \& RENÉ VeGA

Plate 3. Sandersiella chilenica sp.nov. (SEM observations; $\mathrm{T}=$ setal type)

A. Bifid seta $\left(\mathrm{T}_{5}\right)$ on thoracopod 3, found among the long plumose-serrate setae. $\mathrm{x} 2240$.

B. Setal types $\left(\mathrm{T}_{6}\right)$ and $\left(\mathrm{T}_{11}\right.$ with denticles) on endopod of thoracopod 1. Lower right, setae of type $\mathrm{T}_{12} \times 1600$.

C. General view of the "lateral line" (arrows) on the third abdominal segment. x 615.

D. Enlarged view of the "line" showing band of simple setae $\left(\mathrm{T}_{8}\right)$ and larger setae $\left(\mathrm{T}_{9}\right)$ in "pits" (arrows) or close to them. $\mathrm{x} 2000$.

E. Detail of "pits" and setal types $\left(\mathrm{T}_{8}\right)$ and $\left(\mathrm{T}_{9}\right)$. Notice half of the bivalve structure close to a pit. The insertion shows a complete view of one. $\mathrm{x} 8000$.

F. Ventral view of telson and caudal rami showing the long stiff caudal setae $\left(\mathrm{T}_{7}\right)$ and fused setae in serrate spines ("teeth") of pretelsonic $\left(\mathrm{T}_{13}\right)$ and telsonic combs. $\mathrm{x} 168$.

G. Enlargement of serrated spines ("teeth) of the telsonic comb. Notice the typical process of sclerotization and fusion of small setae or spines to form the smaller and larger "teeth". x 1176.

H. Larger spines $\mathrm{T}_{13}$ ("teeth") of the pretelsonic comb. $\mathrm{x} 1200$.

I. Enlarged (ventral) view of the insertion of the four caudal setae $\left(T_{7}\right)$. Notice the vast cover of small spines $\left(T_{12}\right)$ on the ventral part of the abdomen and the caudal rami. x 640 .

Lámina 3. Sandersiella chilenica sp.nov. (microscopia de barrido; $\mathrm{T}=$ tipo de seta )

A. Seta bifida $\left(\mathrm{T}_{5}\right)$ sobre el toracópodo 3, encontrada entre las largas setas plumo-aserradas. x 2240.

B Setas tipos $\left(\mathrm{T}_{6}\right)$ y $\left(\mathrm{T}_{11}\right.$, con dentículos) en últimos segmentos del endopodito del toracópodo 1. Abajo a la derecha setas del tipo $\mathrm{T}_{12} \times 1600$.

C. Vista general de la "línea lateral" (flechas) en el tercer segmento abdominal. x 615.

D. Aumento de la "línea lateral" mostrando la banda de setas simples $\left(\mathrm{T}_{8}\right)$ y las grandes setas en hoyos $\left(\mathrm{T}_{9}\right)$ o cerca de ellos. $\mathrm{x}$ 2000.

E. Detalle de los hoyos y los tipos de setas $\left(\mathrm{T}_{8}\right)$ y $\left(\mathrm{T}_{9}\right)$. Note la mitad de la estructura bivalva en uno de ellos y la inserción mostrando una vista completa de ella. x 8000 .

F. Vista ventral del telson y ramas caudales mostrando las largas setas caudales rígidas $\left(\mathrm{T}_{7}\right)$ y setas fusionadas en los "dientes" de las peinetas pretelsónica $\left(\mathrm{T}_{13}\right)$ y telsónica. x 168 .

G. Aumento de las espinas aserradas (“dientes”) de la peineta telsónica. Nótese el proceso de esclerotización y fusión de pequeñas setas o espinas para formar los “dientes” pequeños y más grandes. x 1176.

H. Espinas grandes $T_{13}$ (“dientes”) de la peineta pretelsónica. x 1200.

I. Vista ventral aumentada de la inserción de las cuatro setas caudales $\left(T_{7}\right)$. Nótese la densa cubierta de pequeñas espinas $\left(T_{12}\right)$ en la parte ventral del abdomen y las ramas caudales. x 640 . 

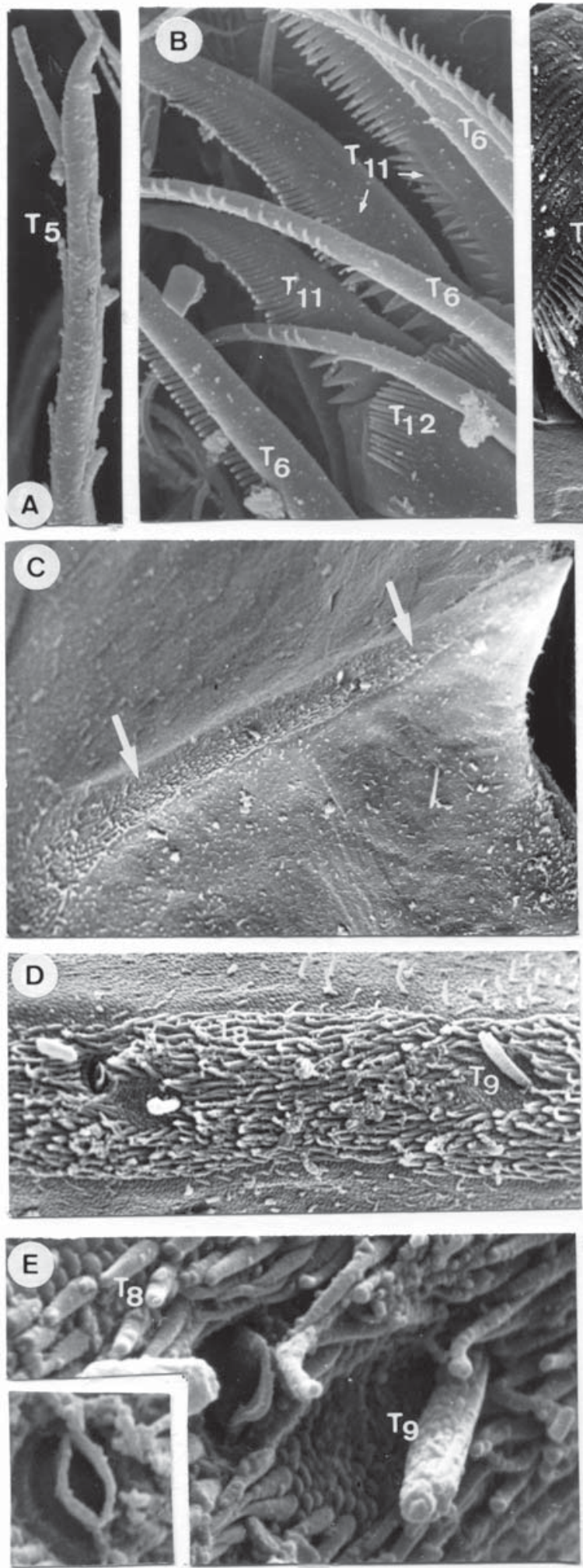

Plate 3.
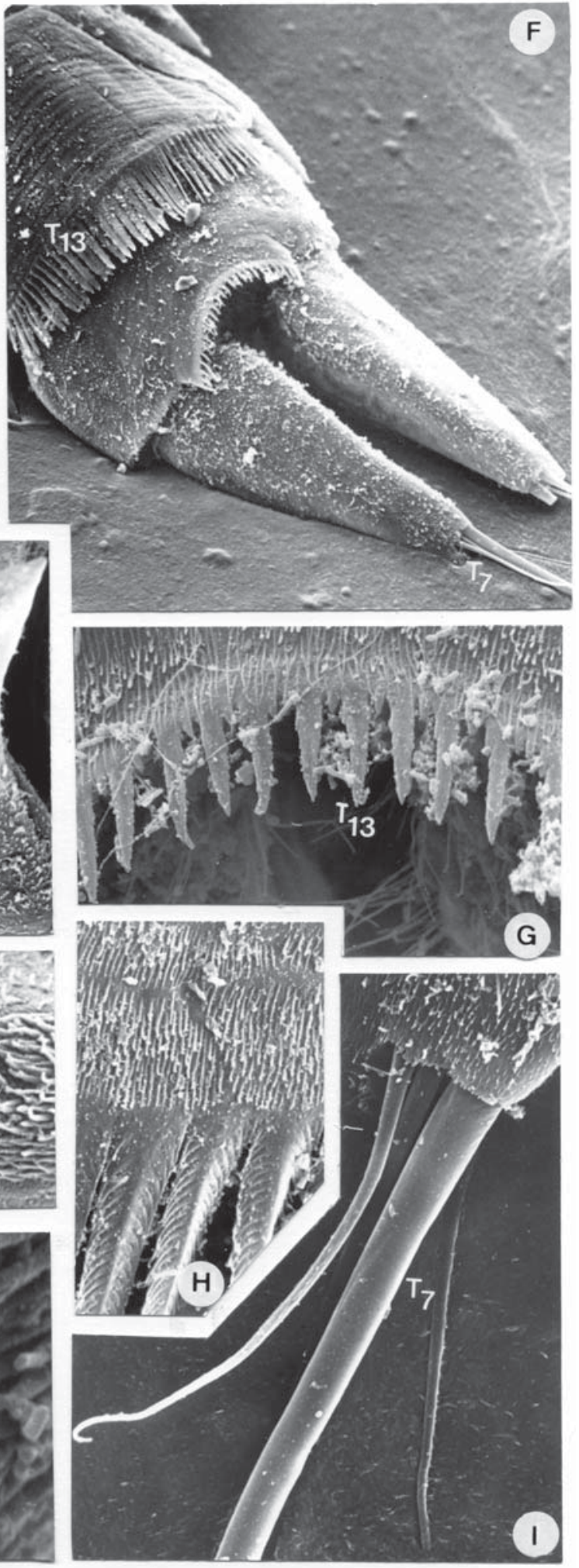
Integumentary structures in Sandersiella chilenica sp. nov.: José R. Stuardo \& René Vega

\section{ACKNOWLEDGMENTS}

We thank Dr. Tarsicio Antezana and Mrs. K. Antezana for criticism and revision of the English, to our friend and former collaborator Biologist Iván Céspedes, who as a young professional helped us in the tyring work of sorting and preserving minute invertebrates from bottom samples, and to several anonimous reviewers whose motivation and experience helped us to improve the contents of this paper.

\section{BIBLIOGRAPHY}

Abele, L.G. 1982. Biogeography (Cephalocarida) In: The biology of Crustacea (Ed. D.E. Bliss) 1: 257-259. Academic Press, New York.

Ache, B.W. 1982. Chemoreception and thermoreception. In: The biology of Crustacea (Ed. D.E. Bliss). 3: 369-398. Academic Press, New York.

Addis, A., F. Biagi, A. Floris, E. Puddu \& M. Carcupino. 2007. Larval development of Lightiella magdalenina (Crustacea, Cephalocarida. Marine Biology. 152 (3): 733-744.

Altner, I., H. Hatt \& H. Altner. 1983. Structural and functional properties of bimodal chemo-and mechanosensitive setae on the pereiopod chelae of the crayfish, Austropotamobius torrentium. Cell and Tissue Research 228 (2): 357-374.

BAstida, R. 1973. Sobre el hallazgo de Crustacea Cephalocarida frente a las costas argentino-uruguayas. Physis, Sección A, Buenos Aires, 32 (84): 220.

Cals, P. \& C. Delamare Deboutteville. 1970. Une nouvelle espèce de Crustacé Céphalocaride de 1' Hémisphère austral. Comptes rendues de 1'Academie des Sciences, Paris, 270D: 2444-2447.

Carcupino, M., A. Floris, A. Addis, A. Castelli \& M. CuriniGallettr. 2006. A new species of the genus Lightiella: the first record of Cephalocarida (Crustacea) in Europe. Zoological Journal of the Linnean Society, 148: 209-220.

Coenlo, V.R., A.B. Williams \& S. De A. Rodrigues. 2000. Trophic strategies and functional morphology of feeding appendages, with emphasis on setae, of Upogebia omissa and Pomatogebia operculata (Decapoda:Thalassinidea: Upogebiiidae). Zoological Journal of the Linnean Society, 130: 567-602.

Crain, J.A. 1999. Functional morphology of prey ingestion by Placetron wosnessenskii Schalfeew Zoeae (Crustacea: Anomura:Lithodidae). Biological Bulletin, 197: 207-218

De Troch M., F. Fiers \& M. Vincx. 2000. Range extension and microhabitat of Lightiella incisa (Cephalocarida). Journal of Zoology, London, 251: 199-204.

Elofsson, R. \& R.R. Hessler. 1990. Central nervous system of Hutchinsoniella macracantha (Cephalocarida). Journal of Crustacean Biology, 10 (3):423-439.

Elofsson, R. \& R.R. Hessler. 1991. Sensory morphology in the antennae of the cephalocarid Hutchinsoniella macracantha. Journal of Crustacean Biology, 11 (3): 343-355.

ELOFSSON, R. \& RR. HeSSLER. 1992. Monoaminergic and peptidergic neurons in the nervous system of Hutchinsoniella macracantha (Cephalocarida). Journal of Crustacean Biology, 12: 531-536.
ElofsSon, R. \& R.R. HessLER. 1994. Sensory structures associated with the body cuticle of Hutchinsoniella macracantha (Cephalocarida). Journal of Crustacean Biology, 14 (3): 454-462.

Elofsson, R. \& R.R. Hessler. 1998. Tegumental glands of Hutchinsoniella macracantha (Cephalocarida). Journal of Crustacean Biology 18: 42-56.

Elofsson, R., R.R. Hessler \& A.Y. Hessler. 1992. Digestive system in the cephalocarid Hutchinsoniella macracantha. Journal of Crustacean Biology, 12: 571-591.

Felgenhauer, B.E. 1992. Chapter 2. External anatomy and integumentary structures. In. Microscopic anatomy of Invertebrates (Ed. F.W.Harrison.), Volume 10: Decapod Crustacea: 7-43, Wiley- Liss, Inc.

GARM, A. 2004. Revising the definition of the crustacean seta and setal classification systems based on examinations of the mouthpart setae of seven species of decapods. Zoological Journal of the Linnean Society, vol.142 (2): 233-252, 11 figures and tables.

Gooding, R.U. 1973. Lightiella incisa sp.nov. (Cephalocarida) from the West Indies. Crustaceana 5: 293-314.

HamiLton, K.A. 1983. A topographical and typological comparison of the rodlike setae of ambulatory dactylopodites in decapod crustaceans. Journal of Morphology, 176 (3): 351364.

Heard, R.W. \& G.D. Goeke. 1982. The occurrence of Lighthiella Jones, 1961 (Crustacea: Cephalocarida) in Mobile Bay, Alabama. Gulf Research Reports 7: 157-162.

Hessler, R.R. 1984. Cephalocarida: living fossil without a fossil record. In: Living Fossils (Eds. Eldredge N. \& S.M.Stanley): 181-186. Springer Verlag New York.

Hessler, R.R. \& R. Elofsson. 1991. Excretory system of Hutchinsoniella macracantha (Cephalocarida). Journal of Crustacean Biology 11 (3): 356-367.

Hessler, R.R. \& R. Elofsson. 1992. Cephalocarida. In: Harrison, F.W., and A.G. Humes, eds. Microscopic Anatomy of Invertebrates, vol.9. Crustacea: 9-24, Wiley-Liss, Inc.

Hessler, R.R. \& R. Elofsson. 1995. Postcephalic podocytes in the thorax of Hutchinsoniella macracantha (Cephalocarida). Journal of Crustacean Biology, 15 (1): 61-69.

Hessler, R.R., R. Elofsson \& A.Y. Hessler. 1995. Reproductive system of Hutchinsoniella macracantha (Cephalocarid a). Journal of Crustacean Biology 15: 493-522.

Hessler, R.R. \& H. SANDERS. 1973. Two species of Sandersiella (Cephalocarida), including one from the deep sea. Crustaceana 24: 181-196.

Hessler, R.R. \& Y. Wakabara. 2000. Hampsonellus brasiliensis n.gen., n.sp., a cephalocarid from Brazil. Journal of Crustacean Biology 20 (3): 550-558, figures and tables.

JoNes, M.L. 1961. Lighthiella serendipita, gen.nov., sp.nov., a cephalocarid from San Francisco Bay, California. Crustaceana, 3: 31-46.

Jones, M.B. \& M.R. Fordy. 1971. A stereoscan electron microscope study of male reproductive characters in the Jaera albifrons group of species. (Crustacea:Isopoda). Marine Biology, 10: 265-271.

KIKUCHI, T. 1969. New locality of Sandersiella acuminate Shiino (Crustacea, Cephalocarida). Publication from the Amakusa Marine Biological Laboratory 2: 33-36.

Knox, G.A. \& G.D. Fenwick. 1977. Chiltoniella elongata n. gen. et 
$s p$. (Crustacea: Cephalocarida) from New Zealand. Journal of the Royal Society of New Zealand 7: 425-432.

Lavalli, K.L. \& J.R. FActor. 1992. Functional morphology of the mouthpats of juvenile lobsters, Homarus americanus (Decapoda: Nephropsidae), and comparison with the larval stages. Journal of Crustacean Biology 12 (3): 467-510,

LAVERACK, M.S. 1968. On the receptors of marine invertebrates. Oceanography and Marine Biology, Annual Review, 6: 249-324.

LaVerack, M. \& Y. Barrientos. 1985. Sensory and other superficial structures in living Marine Crustacea. Transactions of the Royal Society of Edinburgh, 76: 123-136, with figures.

Martin, J.W., D.B. Cadien \& T.L. Zimmerman. 2002. First record and habitat notes for the genus Lighthiella (Crustacea, Cephalocarida, Hutchinsoniellidae) from the British Virgin Islands. Gulf and Caribbean Research 14: 75-59.

McLaughlin, P.A. 1976. A new species of Lightiella (Crustacea: Cephalocarida) from the West coast of Florida. Bulletin of Marine Science. 26: 593-599.

Neira, K. \& M. Palma. 2007. Estructura de la macrofauna en ambientes oxios de Bahía Coliumo, Región del Bío Bío, Chile central. Gayana vol. 71 (2): 156-169.

Oshel, P.E. 1985. Paraffin-carving: a preparative technique for scanning electron microscopy of crustaceans. Journal of Crustacean Biology 5 (2): 327-329.

Pohle, G. \& M. Telford. 1981. Morphology and classification of decapod crustacean larval setae: a scanning electrom microscopy study of Disodactylus crinitichelis Moreira, 1901 (Brachiura: Pinnotheridae). Bulletin of Marine Science, 81: 736-752.

Read, A.T., R.R. Hessler \& C.K. Govind. 1994. Muscle and nerve terminal fine structure of a primitive crustacean, the cephalocarid Hutchinsoniella macracantha. Biological Bulletin, 187: 16-22.

SAnders, H.L. 1955. The Cephalocarida, a new subclass of Crustacea from Long Island Sound. Proceedings of the National Academy of Sciences, USA, 41: 61-66.

SANDERS, H.L. 1957. The Cephalocarida and crustacean phylogeny, Systematic Zoology 6: 112-129.
Sanders, H.L. 1960. Benthic studies in Buzzards Bay. III. The structure of the soft-bottom community. Limnology and Oceanography, 5: 138-153.

SANDERS, H.L. 1963. The Cephalocarida. Functional morphology, larval development and comparative external morphology. Memoirs of the Connecticut Academy of Arts and Sciences, 15: 1-80.

Schiemer, F. \& J. Oтt. 2001. Metabolic levels and microhabitat of an interstitial cephalocarid and micro-isopod. Marine Ecology 22: 13-22.

Schram, F.R. 1986. Crustacea. Oxford University Press, New York, $606 \mathrm{pp}$.

ShIINo, S.M. 1965. Sandersiella acuminata gen. et sp.nov., a Cephalocarid from Japanese waters. Crustaceana, vol.9, pars 2: 181-191.

Shimomura, M. \& T. Akiyama. 2008. Description of a new species of Cephalocarida, Sandersiella kikuchii, and redescription of $S$. acuminata Shiino based upon the type material. Journal of Crustacean Biology, 28(3): 572-579.

Stuardo, J.R., R. Vega \& I. CÉspedes. 1986a. New bopyrid parasitic on Callianassa uncinata $\mathrm{H}$. Milne Edwards: with functional and ecological remarks. Gayana Zoology 50: 3-15.

Stuardo, J.R, R. Vega \& I. Céspedes. 1986b. Comparative external morphology of 3 bopyrid males (Isopoda; Epicaridea) parasitic on Callianassa uncinata H. Milne Edwards. Gayana Zoology 50: 16-36.

Thомаs, W.J. 1970. The setae of Austropotamobius pallipes (Crustacea:Astacidae). Journal of Zoology, London 160: 91-142.

Wakabara, Y. 1970. Hutchinsoniella macracantha Sanders, 1955 (Cephalocarida) from Brazil. Crustaceana 19: 102-110.

Wakabara, Y. \& S.M. Mizoguchi. 1976. Record of Sandersiella bathyalis Hessler and Sanders, 1973 (Cephalocarida) from Brazil. Crustaceana 30: 220-221.

WATLING, L. 1989. A classification system for crustacean setae based on the homology concept. In: Functional Morphology of Feeding and Grooming in Crustacea. Crustacean Issues 6 (Eds. B.E. Felgenhauer, L.Watling and A.B.Thistle), pp: 15-26. A.A.Balkema, Rotterdam, Netherlands.

Recibido: 21.01.11

Aceptado: 06.05.11 